\title{
Pollen-based temperature and precipitation changes in the Ohrid Basin (western Balkans) between 160 and 70 ka
}

\author{
Gaia Sinopoli $^{1,2,3}$, Odile Peyron ${ }^{3}$, Alessia Masi ${ }^{1}$, Jens Holtvoeth ${ }^{4}$, Alexander Francke ${ }^{5,6}$, Bernd Wagner ${ }^{5}$, and \\ Laura Sadori ${ }^{1}$ \\ ${ }^{1}$ Dipartimento di Biologia Ambientale, Sapienza University of Rome, Rome, Italy \\ ${ }^{2}$ Dipartimento di Scienze della Terra, Sapienza University of Rome, Rome, Italy \\ ${ }^{3}$ Institut des Sciences de l'Evolution de Montpellier, University of Montpellier, CNRS, \\ IRD, EPHE, Montpellier, France \\ ${ }^{4}$ Organic Geochemistry Unit, School of Chemistry, University of Bristol, Bristol, UK \\ ${ }^{5}$ Institute of Geology and Mineralogy, University of Cologne, Cologne, Germany \\ ${ }^{6}$ Wollongong Isotope Geochronology Laboratory, School of Earth and Environmental Sciences, \\ University of Wollongong, Wollongong, Australia
}

Correspondence: Alessia Masi (alessia.masi@uniroma1.it)

Received: 18 June 2018 - Discussion started: 6 July 2018

Revised: 3 December 2018 - Accepted: 3 December 2018 - Published: 11 January 2019

\begin{abstract}
Our study aims to reconstruct climate changes that occurred at Lake Ohrid (south-western Balkan Peninsula), the oldest extant lake in Europe, between 160 and $70 \mathrm{ka}$ (covering part of marine isotope stage 6, MIS 6; all of MIS 5; and the beginning of MIS 4). A multi-method approach, including the "Modern Analog Technique" and the "Weighted Averaging Partial Least-Squares Regression", is applied to the high-resolution pollen sequence of the DEEP site, collected from the central part of Lake Ohrid, to provide quantitative estimates of climate and bioclimate parameters. This allows us to document climatic change during the key periods of MIS 6 and MIS 5 in southern Europe, a region where accurate climate reconstructions are still lacking for this time interval.

Our results for the penultimate glacial show cold and dry conditions, while the onset of the "last interglacial" is characterized by wet and warm conditions, with temperatures higher than today (by ca. $2^{\circ} \mathrm{C}$ ). The Eemian also shows the well-known climatic tri-partition in the Balkans, with an initial pre-temperate phase of abrupt warming (128-121 ka), a central temperate phase with decreasing temperatures associated with wet conditions (121-118 ka), followed by a posttemperate phase of progressive change towards cold and dry conditions (118-112 ka).
\end{abstract}

After the Eemian, an alternation of four warm/wet periods with cold/dry ones, likely related to the succession of Greenland stadials and cold events known from the North Atlantic, occurred. The observed pattern is also consistent with hydrological and isotopic data from the central Mediterranean.

The Lake Ohrid climate reconstruction shows greater similarity with climate patterns inferred from northern European pollen records than with southern European ones, which is probably due to its intermediate position and the mountainous setting. However, this hypothesis needs further testing as very few climate reconstructions are available for southern Europe for this key time period.

\section{Introduction}

Since the Middle Pleistocene, the Quaternary is characterized by high-amplitude glacial-interglacial climate variability, occurring cyclically with a $100 \mathrm{ka}$ (kiloanni) periodicity (e.g. Raymo et al., 1989; Tzedakis et al., 1997). The marine isotope stages MIS 6 (penultimate glacial) and MIS 5 (Last Interglacial Complex, LIC) are defined by marine oxygen isotope records ( $\delta^{18} \mathrm{O}$; Lisiecki and Raymo, 2005). MIS 6 is also named the penultimate glacial (Riss glaciation in the alpine area, Late Saale or Saalian Complex in northern and 
central Europe) and can be roughly dated from ca. 190 to ca. $130 \mathrm{ka}$, while MIS 5 lasts from ca. 130 to ca. $80 \mathrm{ka}$ (Govin et al., 2015; Railsback et al., 2015, and references therein). The penultimate glacial is characterized by millennial-scale climate variability (Martrat et al., 2004) and ends by several abrupt events, which are probably related to the icebergrafted debris (IRD) deposition intervals in the north-east Atlantic (McManus et al., 1999). In contrast, the LIC includes the "last interglacial" (roughly equivalent to MIS 5e, or Eemian), followed by a period named "early last glacial" characterized by a succession of stadial (cold and dry conditions) and interstadial (warm and wet conditions) periods (MIS 5d to 5a). These stadials and interstadials correlate to glacial advances or retreats that are documented by ice-rafted debris in North Atlantic sediments (e.g. Bond events and Heinrich events: Bond et al., 1992; Bond and Lotti, 1995) and by changes in oxygen isotope composition in Greenland ice cores (Dansgaard-Oeschger cycles; Dansgaard et al., 1993). Equivalent to the marine isotope stages, the ice core records distinguish Greenland stadials (GS) and Greenland interstadials (GI) where short-lived cold episodes are associated with surface ocean cooling (C events). Across the LIC, seven such cold events (C19-25) have been documented (McManus et al., 1994; Oppo, 2006; Rasmussen et al., 2014).

The Eemian (127-110 ka; Turner 2002; Shackleton et al., 2003) is of particular interest with regard to orbital parameters inducing a strong seasonal forcing of insolation, contrasted vegetation changes (de Beaulieu and Reille, 1992; Zagwijn, 1996) and climatic conditions (Cheddadi et al., 1998; Sánchez-Goñi et al., 2012). Therefore, this period is also considered as a useful target for general circulation models (GCMs) data-model comparison (Kaspar et al., 2005; Otto-Bliesner et al., 2013). In the Northern Hemisphere, the Eemian was wetter (Fauquette et al., 1999; Guiot, 1990; Guiot et al., 1993; Klotz et al., 2003) and by up to $1-2{ }^{\circ} \mathrm{C}$ warmer in summer than the Holocene (Kaspar et al., 2005; Otto-Bliesner et al., 2013; Overpeck et al., 2006;), while sea level was ca. 6-9 m higher (e.g. Kopp et al., 2009). The Eemian thus allows us to study climate dynamics and ecosystem response in a warmer than present Northern Hemisphere without the influence of anthropogenic activity, thereby contributing to assessments of the future impact of the current anthropogenic climate change. Earlier studies of the Eemian considered it a stable, uninterrupted warm period (e.g. Guiot et al., 1993; McManus et al., 1994; Pons et al., 1992; Zagwijn, 1996) with climatic oscillations only recorded in the final part at the transition with the following glacial, i.e. the Weichselian of central and northern Europe, named early Würm in the alpine region (de Beaulieu and Reille, 1984, 1989; Field et al., 1994; Litt et al., 1996). However, more recent studies suggest that low-amplitude climatic fluctuations did occur during the Eemian (e.g. Brewer et al., 2008; Sanchéz-Goñi et al., 2005; Sirocko et al., 2005) and in NGRIP (North Greenland Ice Core Project) ice core isotope records (NGRIP Members, 2004). A pronounced short- lived climatic fluctuation, the intra-Eemian cold event, occurred around $122 \mathrm{ka}$ (Maslin and Tzedakis, 1996). Climate change across the penultimate glacial and the Eemian is documented by numerous pollen records from marine and terrestrial archives (e.g. Govin et al., 2015; Kaspar et al., 2005; Otto-Bliesner et al., 2013). Some of these records have been used for the reconstruction of climatic parameters with a quantitative approach synthesized in Brewer et al. (2008). However, most of these have been carried out using pollen data from European sites located north of $45^{\circ} \mathrm{N}$, while only few reconstructions were carried out in southern Europe. Two are based on pollen continental records, Lago Grande di Monticchio in southern Italy (Allen et al., 2000) and Ioannina in north-western Greece (Tzedakis, 1994) and two on marine pollen records, MD 99-2331 and MD 99-2042 on the Iberian margin (Sánchez-Goñi et al., 2005; Brewer et al., 2008). A first north-south comparison suggests that the two regions may have experienced a somewhat different climatic pattern during the Eemian (Brewer et al., 2008). While both regions experienced an early temperature optimum followed by a cooling trend, towards the end of the Eemian, temperatures and precipitation decreased more strongly in northern Europe compared to southern Europe (Brewer et al., 2008; Sánchez-Goñi, 2007, and references therein). Given that this comparison is based on 13 north European sites and on only 4 south European sites, there is a need to provide more reliable quantitative climate reconstructions in southern Europe for the penultimate glacial, for the Eemian and for the entire LIC in order to improve our understanding of the climate response to climate changes.

The Balkan Peninsula is unambiguously a key region at the confluence of central European and Mediterranean climate influences. The area is rich in extant Quaternary lakes and palaeolakes, with sediment records providing essential information on past vegetation and climate changes going back hundreds of thousands of years, such as Lake Ohrid (Albania and FYROM; e.g. Lézine et al., 2010; Sinopoli et al., 2018; Wagner et al., 2017), Lake Prespa (Albania, FYROM and Greece; Panagiotopoulos et al., 2014), Ioannina (west Greece; Tzedakis et al., 2003), Tenaghi Philippon (north-east Greece; Milner et al., 2016) and Kopais (south-east Greece; Tzedakis, 1999; Okuda et al., 2001). Despite the richness in long palaeoenvironmental archives, quantitative palaeoclimatic reconstructions have been rarely attempted or cover relatively short periods.

In this study, we use a multi-method approach to reconstruct climate parameters between the end of the penultimate glacial (160-128 ka) and the LIC (128-70 ka) inferred from the exceptionally long palynological record $(569 \mathrm{~m})$ of the Ohrid Basin in the western Balkans (Sadori et al., 2016). The palynological data have been acquired from a sediment core from the centre of the lake (DEEP site; Sinopoli et al., 2018). The MIS 6 to MIS 5 transition at Lake Ohrid has been the subject of accurate chronological alignments and synchronizations (Zanchetta et al., 2016) that yield an offset 


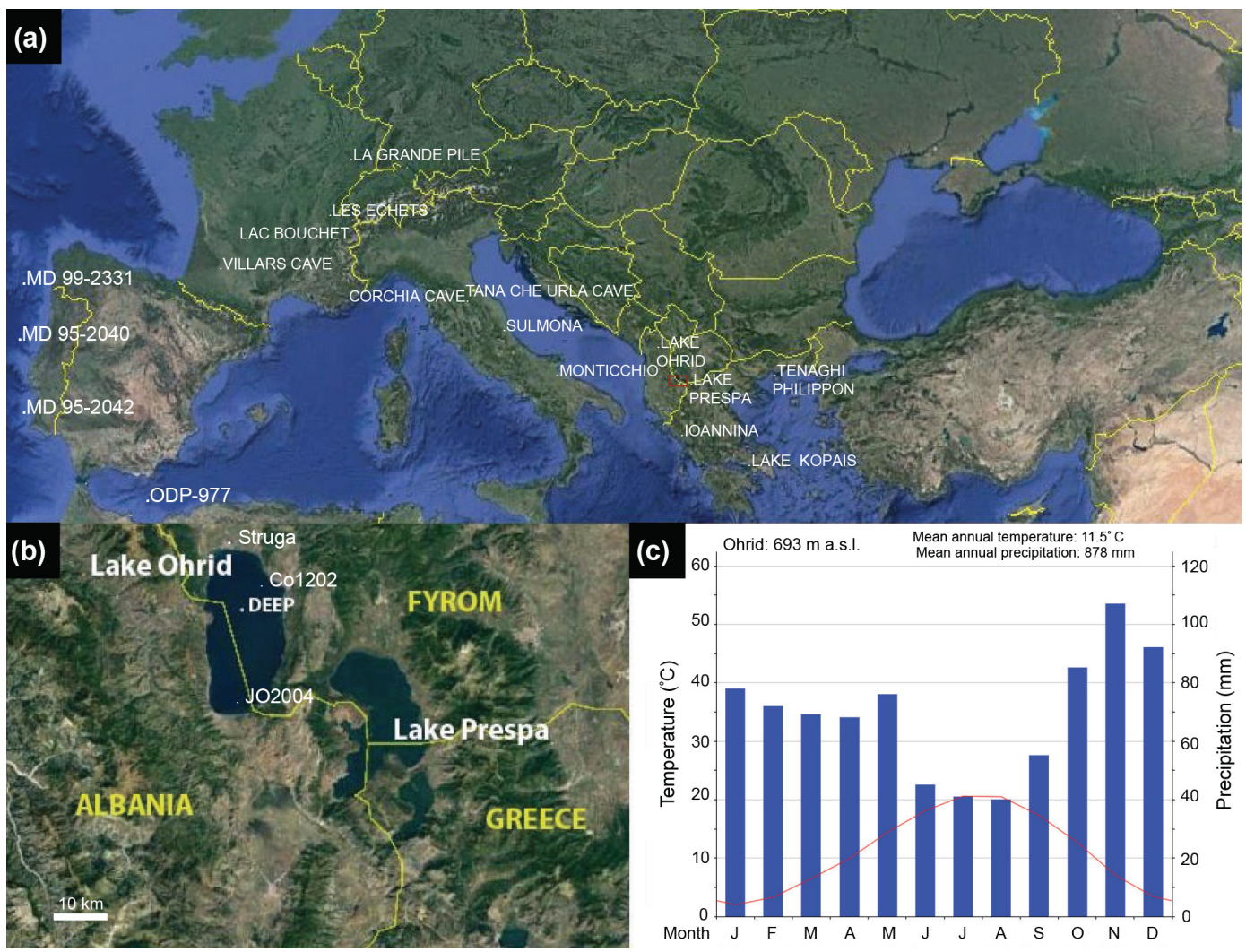

Figure 1. (a) Location map of the Mediterranean records cited in this paper. (b) Location map of Lake Ohrid and its surroundings (US Dept. of State Geographer@ 2017 Google Image Landsat/Copernicus, Data SIO, NOAA, US Navy, NGA, GEBCO) (c). Ombrothermic diagram of Struga meteorological station (http://en.climate-data.org/location/29778/, last access: 17 December 2018).

of $2 \mathrm{ka}$ compared to other records (e.g. Govin et al., 2015; Railsback et al., 2015). The approach for paleoclimate reconstruction applied herein includes two methods frequently used in palaeoclimate reconstructions: the Modern Analog Technique (MAT; Guiot, 1990) and the weighted averaging partial least-squares regression (WAPLS; Ter Braak and Juggins, 1993). In order to test the reliability of our numerical approach, we compare the results to independent climate proxies from the Ohrid Basin such as biomarkers (Holtvoeth et al., 2017) and total inorganic carbon (TIC) concentrations, which largely represent authigenic calcite precipitation (Vogel et al., 2010; Francke et al., 2016). To discuss the climate signal at a more global scale, we compare our results to available pollen-based reconstructions from northern Europe and the Mediterranean, and to marine and terrestrial proxies from the Mediterranean and the Northern Hemisphere (e.g. De Abreu et al., 2003; Drysdale et al., 2005; NGRIP Members, 2004; Lisiecki and Raymo, 2005; Martrat et al., 2004; Regattieri et al., 2014, 2017; Sánchez-Goñi et al., 1999; Wang et al., 2010).

\section{Site description}

Lake Ohrid is located on the Balkan Peninsula at the border between the Former Yugoslav Republic of Macedonia (FYROM) and Albania (Fig. 1). It is probably the oldest lake in Europe, with an estimated age of $>1.2 \mathrm{Ma}$. The lake has a tectonic origin, as its catchment is located in a graben that formed during the Alpine orogenesis between ca. 10-2 Ma. Today, Lake Ohrid has a surface area of $360 \mathrm{~km}^{2}(30 \mathrm{~km}$ long, $15 \mathrm{~km}$ wide, $693 \mathrm{~m}$ a.s.l.), an average depth of $164 \mathrm{~m}$ and a maximum depth of $293 \mathrm{~m}$. The basin is bordered to the west by the Jablanica mountains ( $1514 \mathrm{ma.s.1}$.) and to the east by the Galičica mountains ( 2265 m a.s.l.). The latter separate the watersheds of Lake Ohrid and the adjacent Lake Prespa ( $849 \mathrm{~m}$ a.s.l.), which is located ca. $10 \mathrm{~km}$ to the east, although the two lakes are connected via a karst aquifer system. Apart from inflow from Lake Prespa, Lake Ohrid is supplied with water from surface run-off via small streams, rivers and by direct precipitation. Modern climate in the Ohrid region is Mediterranean with continental influences. The thermal capacity of the lake as well as its proximity to the Adriatic Sea and the local topography affects the local climate. The mean annual temperature recorded in the Ohrid region averages $11.5^{\circ} \mathrm{C}$; temperatures range be- 
tween ca. 2 and $6{ }^{\circ} \mathrm{C}$ in winter (minimum in January) and between 10 and $22^{\circ} \mathrm{C}$ in summer (maximum in July). The morphology of the catchment also affects the wind regime, with northerly winds prevailing during winter and southsoutheasterly winds during spring and summer. The pluviometric regime is Mediterranean, with an average annual precipitation of $878 \mathrm{~mm}$ (Fig. 1).

Lake Ohrid has a rich macrophytic flora (more than 124 species) distributed into different zones dominated by Lemna trisulca L., Phragmites australis (Cav.) Trin. ex Steud., Potamogeton L., Characeae, Ceratophyllum L., Myriophyllum L. and the colonial alga Cladophora spp. The present vegetation around Lake Ohrid belongs to the sub-mediterranean type, in which mediterranean and Balkan elements dominate together with central European ones. The vegetation is sequenced in altitudinal belts, starting from lake level (693 $\mathrm{m}$ a.s.1.) to the top of the mountains (ca. $2200 \mathrm{~m}$ a.s.1.). Riparian forest (dominated by Salix alba L.), with elements of mediterranean vegetation (Fraxinus ornus L., Pistacia terebinthus L. and Phyllirea latifolia L.), is present from the altitude of the lake level to lower elevations together with Buxus sempervirens L., Quercus trojana Webb, Carpinus orientalis L. and Ostrya carpinifolia Scop. Otherwise, forests are characterized by mixed deciduous elements and are mainly composed of Quercus cerris L., Q. frainetto Ten., Q. petraea (Matt.) Liebl., Q. pubescens Willd. up to $1600 \mathrm{~m}$ a.s.1., followed by montane and mesophilous forests (from 1600 to $1800 \mathrm{~m}$ a.s.1.) dominated by Fagus sylvatica L. in association with Carpinus betulus L., Corylus colurna L. and Acer obtusatum (Acer opalus subsp. obtusatum (Waldst. \& Kit. ex Willd.) Gams). Abies alba Mill. and A. borisii-regis Matt. mixed forests grow below $1900 \mathrm{~m}$ a.s.l. at the upper limit of the forested area, while sub-alpine grassland and shrubland with Juniperus excelsa (subsp. polycarpos (K. Koch) Takhtajan) are found above the treeline in mountains situated at south-east of the lake. Towards the east, Pinus peuce Griseb., is present at high elevation, associated with Pteridium aquilinum (L.) Kuhnor, Vaccinium myrtillus L. Sparse population of Pinus species considered to be Tertiary relics are present in the wider area.

\section{Materials and methods}

\subsection{Pollen data from the DEEP core}

A drilling campaign within the scope of the International Continental Scientific Drilling Program (ICDP) was carried out as part of the project Scientific Collaboration On Past Speciation Conditions in Lake Ohrid (SCOPSCO) in 2013. Six parallel cores were recovered from the depocentre of the lake at $243 \mathrm{~m}$ water depth (DEEP site). A composite sequence representing an overall sediment depth of 569 spanning at least the last 1.2 million years has been obtained (Wagner et al., 2017). According to the age model, the up- permost $247.8 \mathrm{~m}$ of the DEEP core cover the last $637 \mathrm{ka}$ (Francke et al., 2016).

Palynological data has been published for the upper $200 \mathrm{~m}$ of the DEEP pollen record, covering the last $500 \mathrm{ka}$, with a time resolution of ca. 1600 years (Bertini et al., 2016; Sadori et al., 2016, 2018). Results have shown an alternation of forested and non-forested periods that are ascribed to five glacial-interglacial cycles. The study presented herein is based on "higher-resolution" pollen data summarized in Fig. 2 (one sample every ca. 400 years; Sinopoli et al., 2018, in the following named "high-resolution").

\subsection{Quantitative reconstruction of temperature and precipitation}

We adopted two different methods in order to improve the error assessment of our approach (e.g. Klotz et al., 2003; Kühl et al., 2010; Peyron et al., 2005, 2011, 2013). It has been demonstrated by several studies that reconstructions based on just one method can have limitations, depending on the time interval and on the methods chosen (Birks et al., 2010; Brewer et al., 2008). Here, we have selected the Best Analogs Approach or Modern Analog Technique (MAT; Guiot, 1990) and the Weighted Average Partial Least-Squares Regression (WAPLS; Ter Braak and Juggins, 1993), two classical methods already used to reconstruct climate changes in the Mediterranean during the Holocene and other time periods (e.g. Brewer et al., 2008; Mauri et al., 2015; Peyron et al., 2011, 2013). Both methods are based on the assumption that climate change strongly influences the distribution and composition of vegetation as every plant species tolerates distinct ranges of temperature and humidity. The MAT is based on the comparison between fossil pollen assemblages and modern ones. The MAT determines the degree of dissimilarity (in terms of taxa abundance and composition) between modern pollen data (associated with known climatic parameters) and the fossil data for which the climatic parameters are to be estimated. For each fossil pollen assemblage, a number of modern pollen assemblages are selected (based on a chord distance calculation) as the closest ones or "analogues". The number of analogues used may affect the quality of the reconstructions. In the present paper, the most robust reconstructions are obtained using six analogues. This is the optimal number of analogues (determined using the lowest rootmean-square error of prediction) in order to minimize the chances of falsely determining two modern samples to be analogues or considering two analogous samples not to be analogues. The method uses the present-day climate data associated with the selected modern analogues to infer the past climate values (Guiot, 1990). In contrast to the MAT, the WAPLS method is a transfer function, which uses a real statistical calibration between climate parameters and modern pollen data. The method is based on unimodal relationships between pollen percentages and climate. In WAPLS, several components are calculated based on weighted averaging al- 
Lake Ohrid - DEEP core

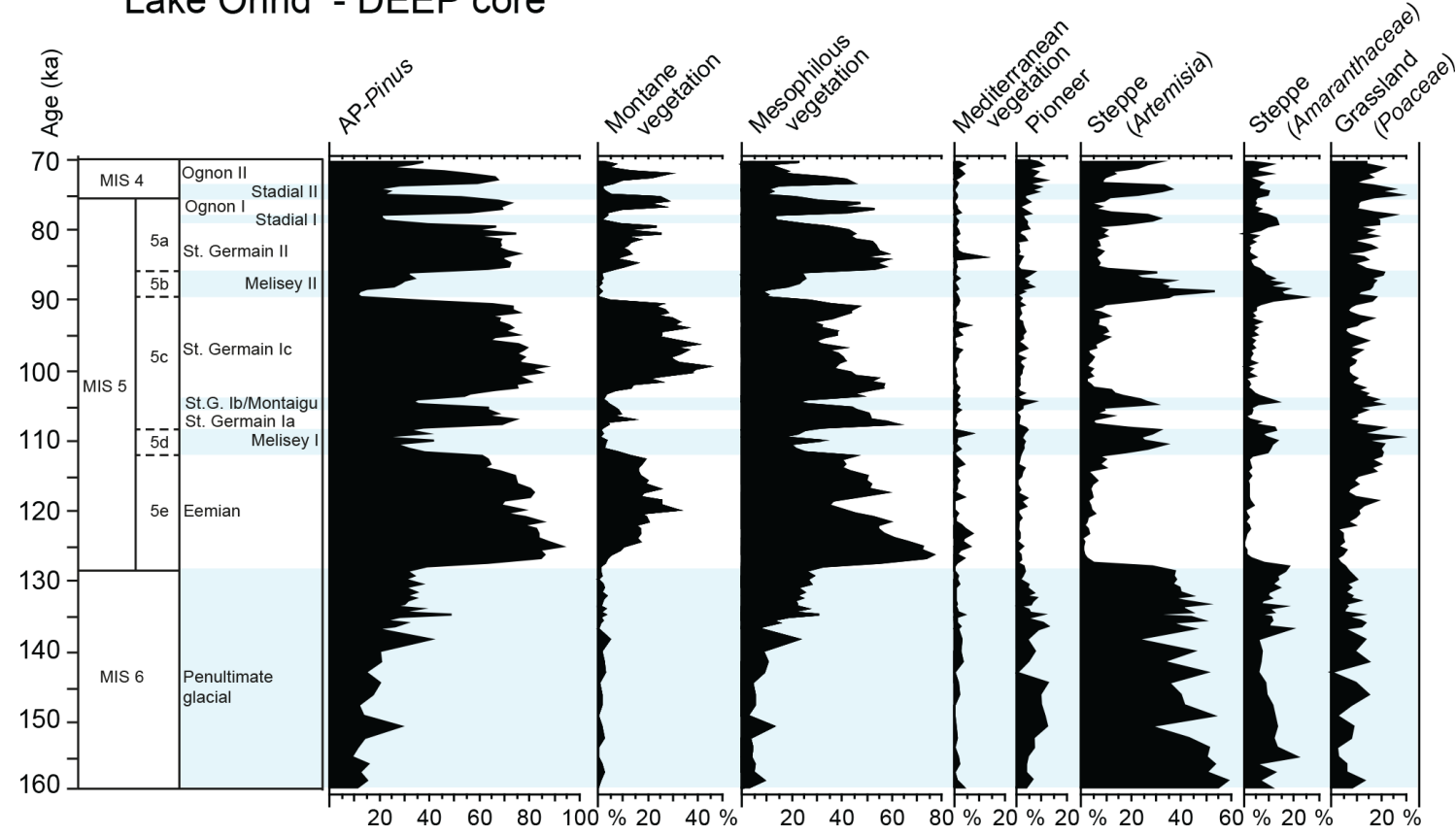

Figure 2. Lake Ohrid (FYROM and Albania) - DEEP core - Pollen percentage diagram of selected taxa and ecological groups against age (ka). Montane vegetation: Abies, Betula, Fagus, Ilex, Picea; mesophilous vegetation: Acer, Buxus, Carpinus betulus, Castanea, Celtis, Corylus, Fraxinus excelsior/oxycarpa, Ostrya/Carpinus orientalis, Hedera, Quercus robur type, Quercus cerris type, Tilia, Ulmus, Zelkova; Mediterranean vegetation: Cistus, Fraxinus ornus, Olea, Phillyrea, Pistacia, Quercus ilex type, Rhamnus; steppe: Artemisia, Amaranthaceae, Chicoriodeae and Asteroideae; and grassland: Poaceae and Cyperaceae. Data from Sadori et al. (2016) and Sinopoli et al. (2018).

gorithms that successively explain more variance in the data; this means that taxa, which better define a climate parameter, are weighted more than the other ones (Ter Braak and van Dam, 1989). A cross-validation has been performed to determine the right number of components (Ter Braak and Juggins, 1993). For both methods, we have used a modern pollen dataset containing more than 3088 samples from European and Mediterranean regions (Peyron et al., 2013). From this dataset, we have excluded those pollen samples collected in warm to hot steppes in order to improve the climate reconstruction during steppic phases (Tarasov et al., 1998). Moreover, Pinus has been excluded due to its overwhelming presence in the DEEP record that potentially masks climatically controlled environmental signals from other taxa. The differences between the two methods probably depend on the lack of present-day European analogues for some glacial vegetation formations.

Five climate parameters have been reconstructed for the DEEP pollen record excluding Pinus (Fig. 3; for the reconstruction with Pinus see Fig. S1 in the Supplement) with each method: (1) the mean temperature of the coldest month (MTCO), (2) the mean temperature of the warmest month (MTWA), (3) the mean annual temperature (TANN), (4) the mean annual precipitation (PANN) and (5) the growing degree days above $5^{\circ} \mathrm{C}$ (GDD5) (Peyron et al., 1998). The analysis was carried out with the software package R, a sys- tem for statistical computation and graphics (R Foundation, https://www.r-project.org/, last access: 17 December 2018) by using the package "rioja" (Juggins, 2016). Error bars have been calculated but are not shown in the figure for graphic clarity. They are available in the Supplement (Fig. S2). Figure S3 indicates the reliability of the analogues selected by reporting the squared-chord distance between the first and the last analogue for a chosen climate parameter (TANN) calculated by the MAT method. The first (last) analogue corresponds to the closest analogue with the low (high) chord distance.

\section{Results}

Previous low-resolution data show that MIS 6 was characterized by a prevalence of Artemisia, Amaranthaceae and Asteroideae since $160 \mathrm{ka}$ (Sadori et al., 2016). During the LIC, high-resolution data provide evidence for forested periods (interglacial and interstadials) alternating with periods of a more open environment (stadials). The pollen analysis revealed that the surroundings of Lake Ohrid during the Eemian were characterized by mesophilous communities prevailing on montane ones (Fig. 2). Forests were mainly featured by expansion of Quercus robur and $Q$. cerris types together with Pinus and Abies (Sinopoli et al., 2018). Trees never completely disappear, being also recorded during sta- 

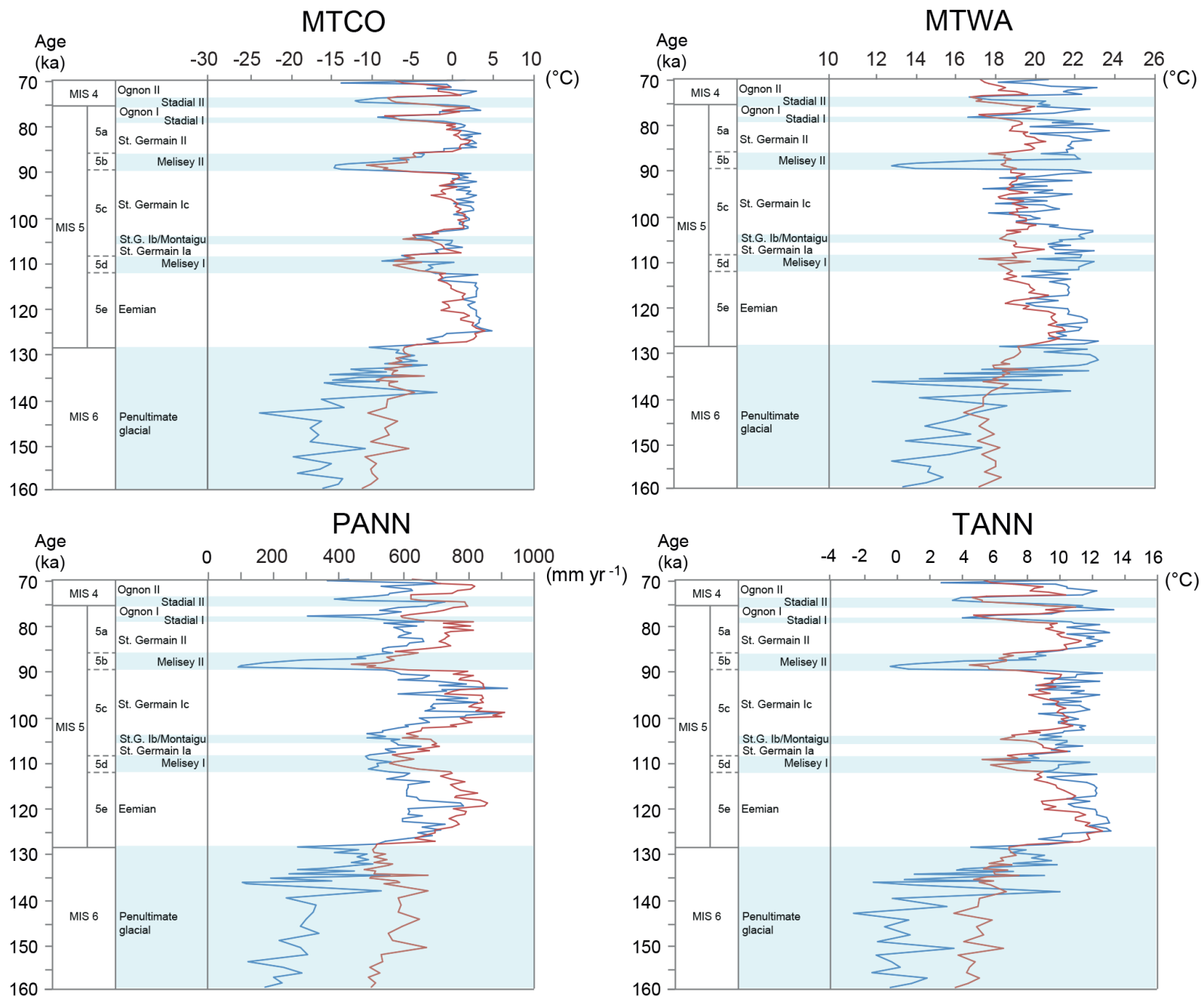

\section{TANN}

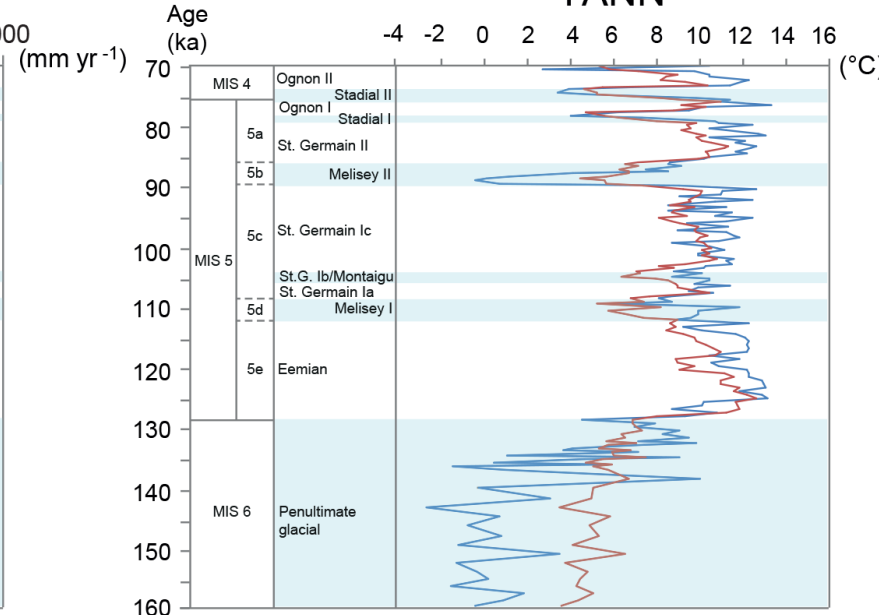

GDD5
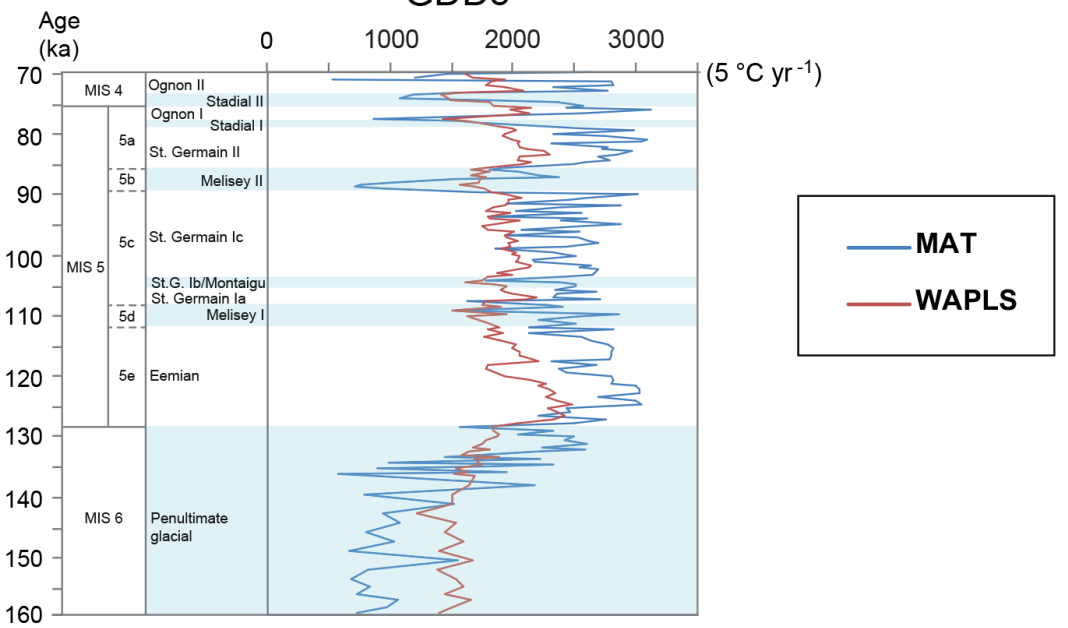

Figure 3. Climate reconstruction inferred from Lake Ohrid pollen data (Sadori et al., 2016; Sinopoli et al., 2018). Climate parameters obtained with the MAT method (blue line) and the WAPLS method (red line): MTCO (mean temperature of the coldest month), MTWA (mean temperature of the warmest month), PANN (mean annual precipitation), TANN (mean annual temperature) and GDD5 (growing degrees days over $5^{\circ} \mathrm{C}$ ). Climate parameter values are plotted against age (ka); they are not expressed in anomalies (past climate value minus the modern measured value). Blue shading indicates cold periods (penultimate glacial and early last glacial stadials). 
dial periods, albeit at low percentages. Here we adopt the terminology used by Woillard (1978) for La Grande Pile pollen record to enhance comparability (see Table 1). We are aware that the marine stratigraphy does not always precisely match the terrestrial one (e.g. Sánchez-Goñi et al., 2007).

Our climate reconstruction suggests cold and dry conditions during MIS 6 and, in MIS 5, an alternation of warm and wet conditions during the Eemian and St. Germain I and II interstadials with cooler and dryer ones occurring during stadials (Fig. 3).

\subsection{The late part of the penultimate glacial (MIS 6, $160-128 \mathrm{ka})$}

The second part of MIS 6 was very cold and dry (Fig. 3) as suggested by the results from both MAT and WAPLS. This portion of the glacial period can be divided into a first part, between 160 and $143 \mathrm{ka}$, which is characterized by cold and dry climate conditions (mean annual temperature below $6{ }^{\circ} \mathrm{C}$ and annual precipitation mainly between 350 and $600 \mathrm{~mm} \mathrm{yr}^{-1}$ ), and a second part, lasting from 143 to $128 \mathrm{ka}$, when several short-term high-amplitude oscillations are reconstructed, especially from 140 to $135 \mathrm{ka}$. These abrupt changes involve all the climate parameters. These oscillations represent significant shifts in mean annual temperature (TANN) and precipitation (PANN), ranging from 2.7 to $10^{\circ} \mathrm{C}$ and from 120 to $600 \mathrm{~mm} \mathrm{yr}^{-1}$, respectively. The GDD5 (growing degrees days over $5^{\circ} \mathrm{C}$, annual accumulated temperature over $5^{\circ} \mathrm{C}$ ) pattern is strongly linked to the MTWA (mean temperature of the warmest month) pattern. The pronounced peak in temperature around $138 \mathrm{ka}$ is probably linked to the high percentages of mesophilous taxa; however, this increase seems overestimated with the MAT. Notably, this oscillation and also the other lower-amplitude oscillations between 143 and $128 \mathrm{ka}$ are more marked in the reconstruction inferred from the MAT (Fig. 3). These values are probably overestimated as the MAT is more sensitive than WAPLS and other methods such as a PDF (probability density function; Brewer et al., 2008; Kühl et al., 2010). Brewer et al. (2008) demonstrated that a wider spread of estimates is found during colder periods and that the analogue methods seem to give a larger variability in time than the other methods, especially during the cold periods.

\subsection{The Last Interglacial Complex, LIC (MIS 5, 128-70ka)}

\subsubsection{The last interglacial (128-112 ka) or Eemian}

The transition to the last interglacial, dated at $128 \mathrm{ka}$, is marked by a rapid rise in temperature and in precipitation, being very close to modern values. The so-called thermal maximum of the Eemian, occurring at Lake Ohrid between 128 and $121 \mathrm{ka}$, is characterized by TANN between 10 and $12{ }^{\circ} \mathrm{C}$, the highest of the investigated period, $2{ }^{\circ} \mathrm{C}$ warmer than the present day (Figs. 3, 5, 6). Winter temperatures were also warmer than today, while summer temperatures were close to modern values and precipitation $100 \mathrm{~mm}$ lower than present day (Figs. 3, 5). A cool event is suggested between 121 and $118 \mathrm{ka}$, while precipitation reaches the highest values of the Eemian at around $119.4 \mathrm{ka}$. After this cool phase, during the last part of the last interglacial (118-112 ka), we reconstruct a progressive cooling and a decrease in precipitation until the end of the Eemian at $112 \mathrm{ka}$.

\subsubsection{The early last glacial (112-70 ka)}

The early last glacial (Table 1) is characterized by an alternation of short cold and dry periods with longer warm and wet ones.

- Warm and wet interstadial periods: St. Germain I (108$90.2 \mathrm{ka}$ ), St. Germain II (85.7-78.8), Ognon I (77.6$75 \mathrm{ka})$, Ognon II (73.4-69.9 ka).

- Cool and dry stadial periods: Melisey I (112-108 ka), Montaigu (105.2-104 ka), Melisey II (90.2-85.7 ka), stadial I (78.8-77.6 ka), stadial II (75-73.4 ka).

\section{Interstadials: warm and wet conditions}

The first interstadial following the Eemian (Fig. 3) corresponds to the St. Germain I (108-90.2 ka) that can be divided (Table 1) into three parts, two of which, St. Germain Ia (108-105.2 ka) and St. Germain Ic (104-90.2 ka), are warm and wet, while the other, Melisey II (105.2-104 ka), is cold and dry. During St. Germain Ia, both TANN and PANN increase suggesting that the St. Germain I was warm and wet, but still to a lower extent than the Eemian. In contrast, the St. Germain Ic appears to be wetter and overall warmer than St. Germain Ia (Fig. 3). The precipitation increases strongly and reaches values between ca. 600 and $900 \mathrm{~mm} \mathrm{yr}^{-1}$, which is the wettest period between 160 and $70 \mathrm{ka}$. A pronounced dry event is centred at $95.3 \mathrm{ka}$. The second interstadial (85.7$78.8 \mathrm{ka}$ ) corresponding to St. Germain II is characterized by temperate conditions comparable to those of St. Germain Ic (104-90.2 ka) even if it seems drier. The following two interstadials corresponding to the Ognon I and II (77.6-75 and 73.4-69.9 ka) show climate conditions comparable to those occurring during the second interstadial (Fig. 3).

\section{Stadials: cold and dry conditions}

The temperate conditions of the last interglacial are interrupted by a first cooling event corresponding to the stadial Melisey I (112-108 ka) characterized by cold and dry conditions (Fig. 3). A second abrupt event is recorded between 105.2 and $104 \mathrm{ka}$, namely during the Montaigu cooling (St. Germain Ib) that divides the St. Germain I into two "interstadials". During this event, precipitation reaches values similar to those of the previous stadial (Melisey I). Temperature and precipitation follow the same pattern with a strong 
Table 1. Correlation of nomenclature defined by Woillard (1978) for La Grande Pile (NE France) with common terrestrial nomenclature and the marine isotope stages (MIS; Lisiecki and Raymo, 2005). This is just a scheme and a precise correspondence between MIS 5 substages and the terrestrial phases defined by Woillard (1978) is not yet precisely established.

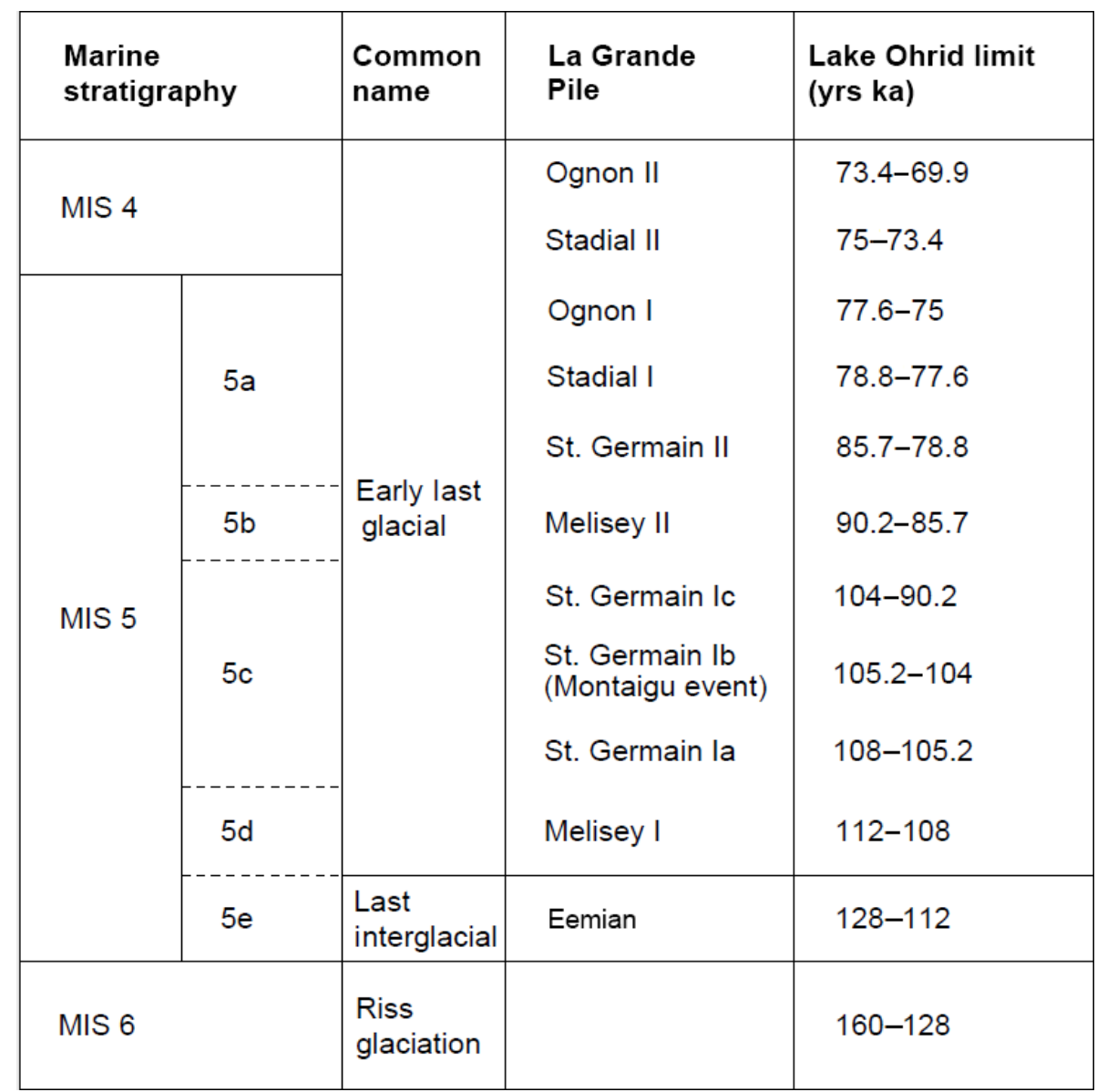

decrease at 104.6 ka. Melisey II (90.2-85.7 ka) appears as the coldest and driest event of the early last glacial (Fig. 3), with a strong temperature and precipitation decrease evidenced by both methods. As during the end of MIS 6, the cooling reconstructed with the MAT is probably overestimated given that the analogue method provides a large variability during the cold periods. However, the climate was certainly very cold during Melisey II, particularly in winter as illustrated by the WAPLS. Precipitation reaches extremely low values, dropping to ca. $100 \mathrm{~mm} \mathrm{yr}^{-1}$, which is even lower than in MIS 6 but here too the drying seems overestimated with the MAT for the same reasons as temperatures. The following two stadials (78.8-77.6 and 75-73.4 ka) should indicate a pattern very similar to Melisey II, with an abrupt decrease in temperature and precipitation followed by a likewise abrupt increase at the end of each phase (Fig. 3).

\section{Discussion}

\subsection{Differences between MAT and WAPLS and reliability of the methods}

The temperature reconstructions from both methods are reasonably coherent (trends and values) during the interglacial and interstadials, but a wider spread of estimates is found during colder periods (Fig. 3) for which the analogues method suggests higher-amplitude oscillations and lower values than those inferred by the transfer function (Fig. 3). More precisely, during ca. 160-143 ka, both methods produce lowamplitude oscillations in temperatures, but the values determined by MAT appear to be around $4{ }^{\circ} \mathrm{C}$ lower than those determined by WAPLS. Even if the precipitation curves produced by both methods show the same trend, reconstructed values by MAT are roughly $300 \mathrm{~mm}$ lower than those resulting from WAPLS. After $143 \mathrm{ka}$, the differences between the two methods are more pronounced (Fig. 3). It is worth mentioning that WAPLS precipitation values are inside the error bars (Fig. S1). Discrepancies between the methods may be 
related to several factors that either depend on the method itself or on the composition of past pollen assemblages. As mentioned in Sect. 3.2 modern analogues methods are very sensitive to minor variations in the pollen assemblages, especially during glacial periods (Brewer et al., 2008). Similar discrepancies associated with MAT also occur in the reconstruction of La Grande Pile; strong cold and dry oscillations are evidenced (and probably overestimated) after the Eemian thermal optimum by Brewer et al. (2008). MAT is frequently used to reconstruct the climate of the Late Glacial and Holocene (e.g. Mauri et al., 2015; Peyron et al., 2005) but, as demonstrated by Guiot et al. (1993), ambiguous outcomes may occur particularly for past glacial and cold intervals (stadials). The major problem appears to be the lack of modern analogues or only limited similarity with past glacial vegetation (Guiot et al., 1993; Peyron et al., 1998). Indeed, as reported in several studies (Guiot, 1987; Guiot et al., 1993; Klotz et al., 2003), glacial steppe vegetation dominated by high percentages of Amaranthaceae (as at Lake Ohrid, Fig. 2) has no present-day analogue in Europe. For this reason, we have used modern samples from cold steppe principally from the Tibetan Plateau and from Russia as "potential" analogues for glacial periods (Peyron et al., 1998, 2005). Squared-chord distance has been used to determine the degree of dissimilarity (Fig. S1), revealing that our reconstruction can be judged reliable and without a no-analogs situation occurring. The differences between the two methods for cool/cold periods may also be ascribed to the quasi-continuous presence of arboreal taxa in steppic assemblages. During the period between 143 and $128 \mathrm{ka}$, the major oscillations are probably overestimated and likely linked to the presence of arboreal mesophilous (temperate) taxa in steppic pollen assemblages. Mesophilous taxa amount to $10 \%-30 \%$, with a prevalence of deciduous and semi-deciduous oaks, while pioneer shrubs are between $5 \%$ and $10 \%$, with prevalence of Juniperus (Fig. 2). This discrepancy attests to the specific local hydroclimatic features of the Ohrid Basin and its fundamental role as a refugium for many arboreal taxa. Considering the very high sensitivity of the MAT, WAPLS seems to be a better method to reconstruct the climatic changes during cold events in refuge areas.

\subsection{Climate changes at Lake Ohrid: comparison with independent proxies and other climate reconstructions}

Our data are in agreement with climate signals depicted in geochemical data from the DEEP site (Francke et al., 2016; Wagner et al., 2017) and other Lake Ohrid cores (core JO2004 from the south of the lake; Bordon, 2008; core Co1202 from the north-east; Holtvoeth et al., 2017; see Fig. 1; Vogel et al., 2010). When comparing our results to the Eemian climate reconstruction of JO2004 (Bordon, 2008), the trends are similar, while some differences in temperature and precipitation values should be pointed out. They proba- bly result from differences in pollen assemblages due to the different positions of the analysed cores. Core JO2004 was retrieved from the southern part of the lake, closer to the lake shoreline. Therefore, its pollen assemblages show increased values of local taxa and of those not dispersed over long distances; in contrast, these taxa are found in lower abundance or not at all in the central part of the basin from where the DEEP core was retrieved. Due to the central position of the DEEP and the morphology of the territory around the lake (vegetation organized in altitudinal belts) we assume that our climate reconstruction integrates the palynological signal of the surrounding mountain ranges and, consequently, our data accounts for a regional and not a local climate reconstruction. In Fig. 4, the temperature and precipitation (PANN and TANN) signals are compared to the TIC and the total organic carbon (TOC) records from the DEEP core and to the TIC and TetraEther indeX of archaeal lipids $\left(\right.$ TEX $\left._{86}\right)$ from core Co1202. For more information about these proxies see Francke et al. (2016), Vogel et al. (2010), Holtvoeth et al. (2017) and references therein. All proxies reported in Fig. 4 are used as indicators for environmental and climatic change. Concerning proxies from the DEEP core, PANN and TANN resemble TIC and TOC. TIC concentrations and precipitation of mainly authigenic carbonate is controlled by water temperature and productivity, but also by ion concentrations in the lake, which depend on precipitation and the activity of the karst aquifer system (Vogel et al., 2010; Francke et al., 2016). Minima in TOC that correspond to minima in TANN indicate that these minima are the result of restricted productivity combined with increased decomposition of organic matter due to the prolonged winter season and enhanced mixing of the water column (Francke et al., 2016). However, TOC reflects autochthonous and allochthonous organic matter input, i.e. supply of biomass from both the lake as well as the surrounding land (Francke et al., 2016; Holtvoeth et al., 2017; Zanchetta et al., 2018). The productivity of the terrestrial vegetation and supply of terrestrial organic matter to the lake seem to be largely controlled by precipitation rather than temperature; thus, explaining similarities with the PANN record. While TIC and TOC may co-vary at times they are not generally causally related. During MIS 6, TIC is mostly very low, suggesting cold and dry climate conditions (Francke at al., 2016), in agreement with the pollen-inferred mean annual temperature and precipitation (Fig. 4). At the transition toward MIS 5, TIC and $\mathrm{TEX}_{86}$ values increase together, indicating a warming and augmentation of humidity, consistent with the increase in PANN and TANN inferred from pollen. The distinct highamplitude fluctuations inferred from pollen during the final part of MIS 6 could at least partly be due to lake-level changes as the water table during this period was generally on the rise (Lindhorst et al., 2010; Holtvoeth et al., 2017; Wagner et al., 2017). As mentioned before, the (modern) lake basin and parts of the lake floor show a pronounced terraced morphology. The relatively rapid flooding of extended, 
nearly horizontal surfaces, in particular at the northern and southern ends of the lake, may thus have diminished sizeable parts of (flat) terrestrial habitat in short periods of time. The impact of lake-level change on the low-lying terrestrial habitats could be clearly seen in the biomarker and pollen records of core Co1202 (Holtvoeth et al., 2017). While localized processes are likely averaged out by the longer-distance transport of material towards the distal DEEP site, a basinwide effect of lake-level change and the associated distribution of low-lying biomes in the north, northeast and south of the basin might have to be considered in order to explain the observed fluctuations in the PANN and TANN records of the DEEP core between 136 and $130 \mathrm{ka}$ precipitation-controlled lake-level change may have affected the surface area of lowlying terrestrial habitats on terrace surfaces before the temperature threshold for the precipitation of authigenic carbonate (TIC) was crossed, leading to the 2000 or 3000 years offset in the beginning of the high-amplitude fluctuations in pollen-derived PANN and TANN records and the rise in TIC.

The beginning of the last interglacial is almost synchronous as indicated by the records of TIC (DEEP), carbonate and $\mathrm{TEX}_{86}$ (Co1202, Fig. 4). However, according to the TIC and TEX $_{86}$ records of Co1202, the thermal maximum, characterized by stable conditions, occurs between 126.5 and $124 \mathrm{ka}$ in contrast to our reconstructed temperature that increases earlier at $127 \mathrm{ka}$. This slight discrepancy is probably due to differences in the chronology established independently for the two cores. An explanation for the delay of TIC values takes into account the time needed for the dissolution of calcite from the surrounding rocks and/or dissolution of endogenic calcite after deposition (see Francke et al., 2016). At long timescales, calcite precipitation occurs during periods of high precipitation such as interglacials and interstadials when supply of calcium and carbonate ions from calcite dissolution into the lake increases, and/or elevated temperature and high evaporation occur. Biogenic calcite formation is hampered during dry and cold periods (glacial and stadials) due to decreased precipitation and associated nutrient supply to reduced terrestrial calcite dissolution and inflow of dissolved carbonate from the karst system (Lézine et al., 2010). Soon after the "thermal maximum" (128-121 ka) TIC values decrease together with mean annual temperature; by contrast, at the same time precipitation rises. The low TIC content can be explained by lower water temperature, which hampers calcite precipitation. Slight progressive drying occurs from $121 \mathrm{ka}$ until the end of the Eemian at $112 \mathrm{ka}$. This trend corroborates the climate reconstruction based on core JO2004 (Bordon, 2008) and confirms the assumption that the Last Interglacial was not a uniform wet and warm phase in western Europe (e.g. Cheddadi et al., 1998; Guiot et al., 1993; Klotz et al., 2004; Kühl and Litt, 2003; Rousseau et al., 2006; Sánchez-Goňi et al., 2005) and that successive cool and dry events occur at ca. 110 and $105 \mathrm{ka}$.

\subsection{Comparison with European climate reconstructions inferred from pollen records}

Lake Ohrid's chronology is well established for MIS 5 due to the high number of tephra layers (Francke et al., 2016; Leicher et al., 2016), in particular for the transition between the Riss glaciation and the Eemian, for which a further correlation with geochemical and pollen data from Lake Ohrid and other proxies from Mediterranean sequences was carried out by Zanchetta et al. (2016). For other European pollen records such chronological constraints are not available and thus the chronologies are probably less precise. Keeping in mind the existing chronological uncertainties, a comparison of precipitation and temperature anomalies is carried out, with the values inferred from three other long pollen records (Fig. 5) spanning the interval between 140 and $70 \mathrm{ka}$ : Les Echets, Le Bouchet and La Grande Pile (Fig. 1). Lake Ohrid, despite being considered as "a southern site", shows past climate trends similar to the French records (Fig. 5). This similarity is probably due to its high elevation, causing enhanced precipitation relative to the rest of southern Europe and making it similar to regions directly subjected to the North Atlantic circulation. In order to discuss Lake Ohrid's climate record more in depth on a European scale, a further comparison is shown in Fig. 6. Here, Lake Ohrid climate anomalies are plotted with the ones estimated by Brewer et al. (2008) for southern and central-northern European sites, using a pollen-inferred multi-method approach that takes into account the various sources of errors in paleoclimate reconstructions. The investigated interval is, in this case, limited to the period 135-105 ka, which includes the whole Eemian (ca. MIS 5e-d according to Sánchez-Goñi, 2007). During the final part of MIS 6 (Figs. 3, 6), climate seems to have been particularly harsh at Lake Ohrid, with highly reduced precipitation compared to other European sites (Brewer et al., 2008) or to the present. However, the precipitation anomaly values are comparable to those of the French sites (Fig. 5). For the latter, we have to consider that the same methods have been applied, which could have resulted in the more consistent values. There are opposite trends, difficult to interpret, in the anomalies at the end of MIS 6 in the considered records. La Grande Pile, Les Echets and Le Bouchet reconstructions show a "thermal maximum", the so-called climate optimum, from 127 to $118 \mathrm{ka}$ followed by an abrupt cooling around $117 \mathrm{ka}$ (Fig. 6 and Brewer et al., 2008). The signal reconstructed for northern Europe is different from the French sites; Brewer et al. (2008) had identified a climate tri-partition during the Eemian, already evidenced by Tzedakis (2007, and references therein): early optimum, followed by slight cooling, followed by a sharp drop in temperatures and precipitation. This set of changes appears to be restricted to the north, with a very different set of changes in the south. In southern Europe, the Eemian climate appears to have remained warm with stable conditions over a long period between 126 and $105 \mathrm{ka}$ (Fig. 6). Lake Ohrid is located 


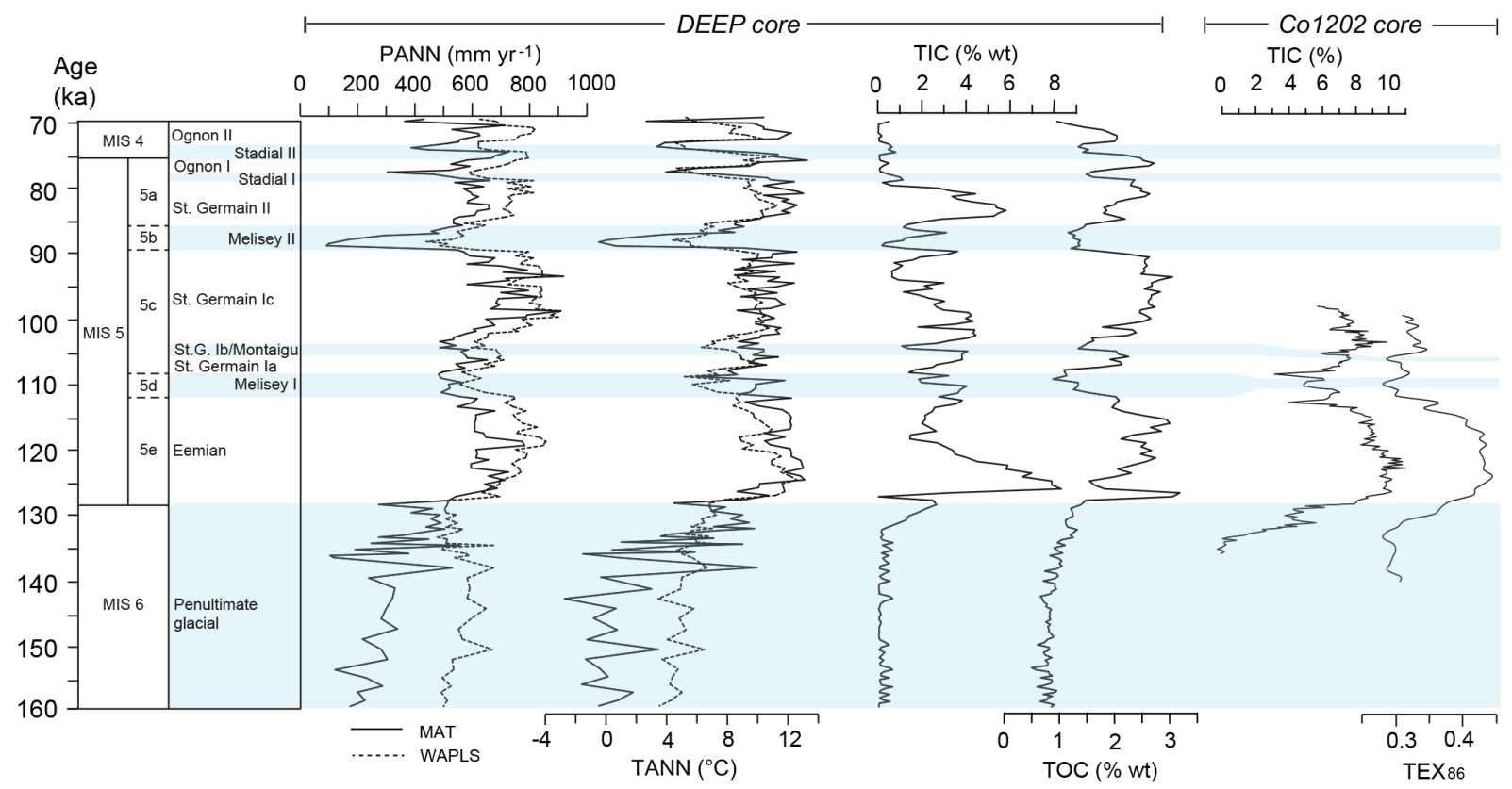

Figure 4. Lake Ohrid: comparison between DEEP core annual temperature (TANN), precipitations (PANN) and TIC (Francke et al., 2016) with TIC and TEX 86 (Co1202 core; Holtvoeth et al., 2017). Blue shading indicates cold periods (penultimate glacial and early last glacial stadials).

in a central position on the Balkans Peninsula, at the confluence of central European and Mediterranean climates. The Lake Ohrid climate reconstruction also shows a climate optimum in the early part of the Eemian and then a progressive cooling without a sharp drop in temperatures and precipitation (Fig. 6); this suggests an intermediate climate signal, more similar to the French sites (Fig. 5) than to the northern or southern European ones (Fig. 6). Brewer et al. (2008) show that climate changes during this period were heterogeneous, with greater winter warming in the centre and northeast of Europe than in the west and north-west. Other studies of the spatial distribution of temperature changes during this period have shown similar trends in temperature, with the largest positive anomalies in central and northern Europe, and negative anomalies in south-eastern Europe (Kaspar et al., 2005; Turney and Jones, 2010; Otto-Bliesner et al., 2013). Furthermore, one remaining question is whether the climate of this period was very close to modern values or warmer and wetter than the present day as suggested by existing studies (Guiot et al., 1989). The time series of anomalies presented here (Fig. 5) suggest a positive anomaly of 1 to $2{ }^{\circ} \mathrm{C}$ for the Ohrid Basin, strongly depending on the method used. Melisey I is the first cooling event, with a significant reduction in temperatures and precipitation, although less pronounced than at the French sites (Fig. 5). At Lake Ohrid, a surprising positive anomaly in the middle of Melisey I is suggested and is potentially due to the persistence of trees during stadials, highlighting the important role of the Ohrid Basin as a refugium for arboreal taxa. Ac- cording to several studies carried out in central and northern Europe (Guiot et al., 1993; Klotz et al., 2004; Rioual et al., 2001), the Melisey I event is characterized by an abrupt decline in temperatures first, followed by increasing continental conditions, with a subsequent decline in winter temperatures and an increase in summer temperatures. Other pollen records from Lake Ohrid also strongly suggest that climatic conditions remained favourable to grow mesophilous taxa (Bordon, 2008; Holtvoeth et al., 2017; Lézine et al., 2010). St. Germain Ia (Figs. 3 and 5) is drier than St. Germain Ic at Lake Ohrid, with the latter showing annual precipitation up to ca. $400 \mathrm{~mm} \mathrm{yr}^{-1}$ higher than during the former. The values are consistent with the data obtained by Klotz et al. (2004) for central Europe, more specifically in the northern Alpine foreland. The same trend is also recorded in the French sites presented here (Fig. 5). Melisey II appears as the most extreme stadial of the LIC, coinciding with the maximum extension of ice sheets during the Early Weichselian. However, the cooling reconstructed at Ohrid is probably overestimated with the MAT for the same reasons as during MIS 6. If we consider the WAPLS reconstruction, the anomalies estimated at Ohrid during Melisey II are $2{ }^{\circ} \mathrm{C}$ higher than for the French sites (Figs. 3 and 5). During St. Germain II, temperature and precipitation values for Lake Ohrid are similar to those of St. Germain Ia (Figs. 3 and 5). This pattern is corroborated by other studies for the North Atlantic, using marine $\delta^{18} \mathrm{O}$ data (Keigwin et al., 1994), for North Europe (e.g. Guiot et al., 1989) and for the Iberian margin (Sánchez-Goñi et al., 2000). At the end of the interstadial, a trend towards low 


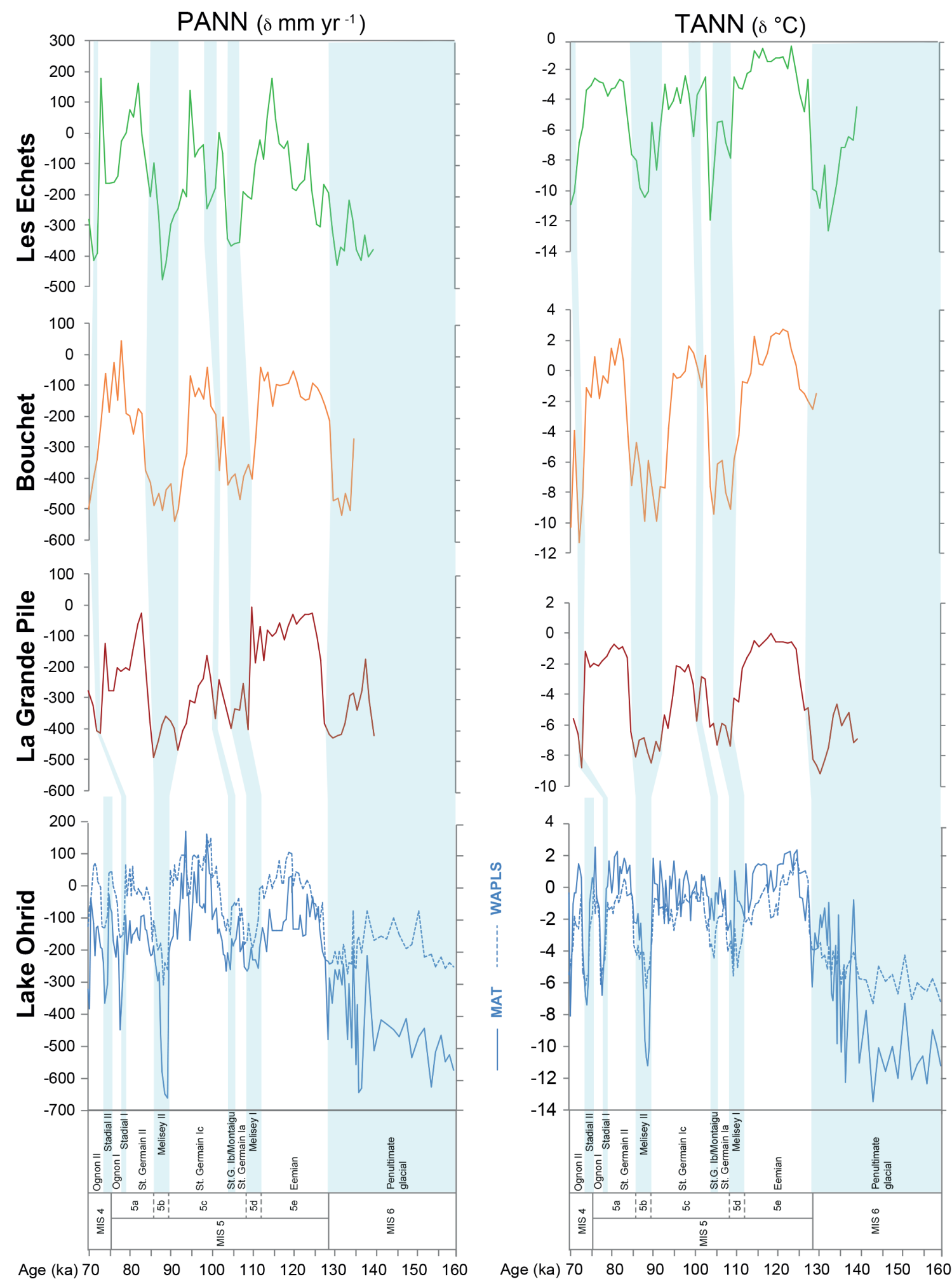

Figure 5. Comparison between Lake Ohrid climate parameters with available climate reconstructions: Les Echets (265 m a.s.1.), Le Bouchet (1200 m a.s.1.) and La Grande Pile (330 m a.s.1.) from Guiot et al. (1989, 1990, 1993). TANN (mean annual temperature) and PANN (mean annual precipitation) are plotted against age $(\mathrm{ka})$. Values represent anomalies (past climate value minus the modern measured value). Blue shading indicates cold periods (penultimate glacial and early last glacial stadials). 


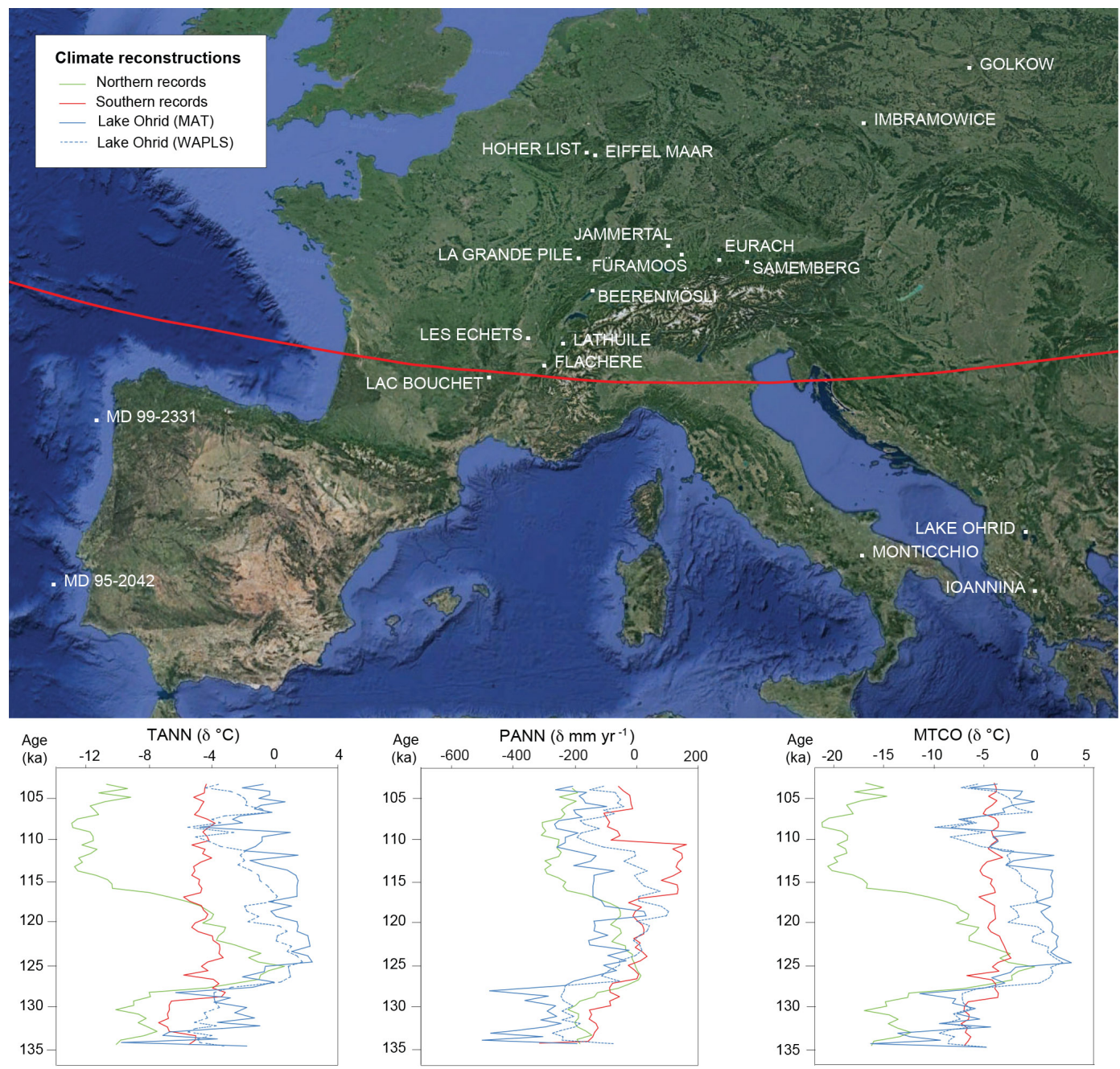

Figure 6. Comparison between the Lake Ohrid climate reconstruction and the climate reconstruction performed by Brewer et al. (2008) for north and south Europe; TANN (mean annual temperature), PREC (mean annual precipitation) and MTCO (mean temperature of the coldest month) are plotted against chronology (ka). Values represent anomalies (past climate value minus the modern measured value).

temperatures and an increase in precipitation is recorded at Lake Ohrid, in agreement with the climate reconstruction of Guiot et al. (1989) for the French pollen records (Fig. 5). The most striking feature of Lake Ohrid, recorded at the top of the studied sequence, is the presence of two interstadials following St. Germain II, namely Ognon I and Ognon II. These interstadials are visible, even if less marked in other eastern Mediterranean records (Tenaghi Philippon; Müller et al., 2011; Lake Van: Pickarski et al., 2015) and could be correlated with the Dansgaard-Oeschger events DO 19 and 20 (Dansgaard et al., 1993).

\subsection{Comparison with other European and North Atlantic proxy records}

In order to discuss the Ohrid climate signal at a wider scale, Fig. 7 shows the correlation of the reconstructed climate pa- rameters with marine and continental proxies from Mediterranean and North Atlantic regions (Fig. 1).

In speleothem and lake sediment records, $\delta^{18} \mathrm{O}$ is mostly seen as an indicator of the "amount of precipitation", lower (higher) values are related to increasing (decreasing) humidity (Bard et al., 2002; Drysdale et al., 2005, 2009; Regattieri et al., 2014; Zanchetta et al., 2007, 2016). The Ohrid precipitation trend shows similarities with the oxygen isotope records reported in Fig. 7, suggesting a generally good agreement with the variations in Mediterranean rainfall detected in Italy in speleothems from Antro del Corchia and Tana che Urla (Drysdale et al., 2005; Regattieri et al., 2014) and in the lake record of Sulmona (Regattieri et al., 2017). According to Drysdale et al. (2009), there is a break in the decrease in $\delta^{18} \mathrm{O}$ in continental and marine values prior to the beginning of the Eemian at ca. $129 \mathrm{ka}$, which can be related to Heinrich event 11 (H11; Shackleton et al., 2003). During this event, 


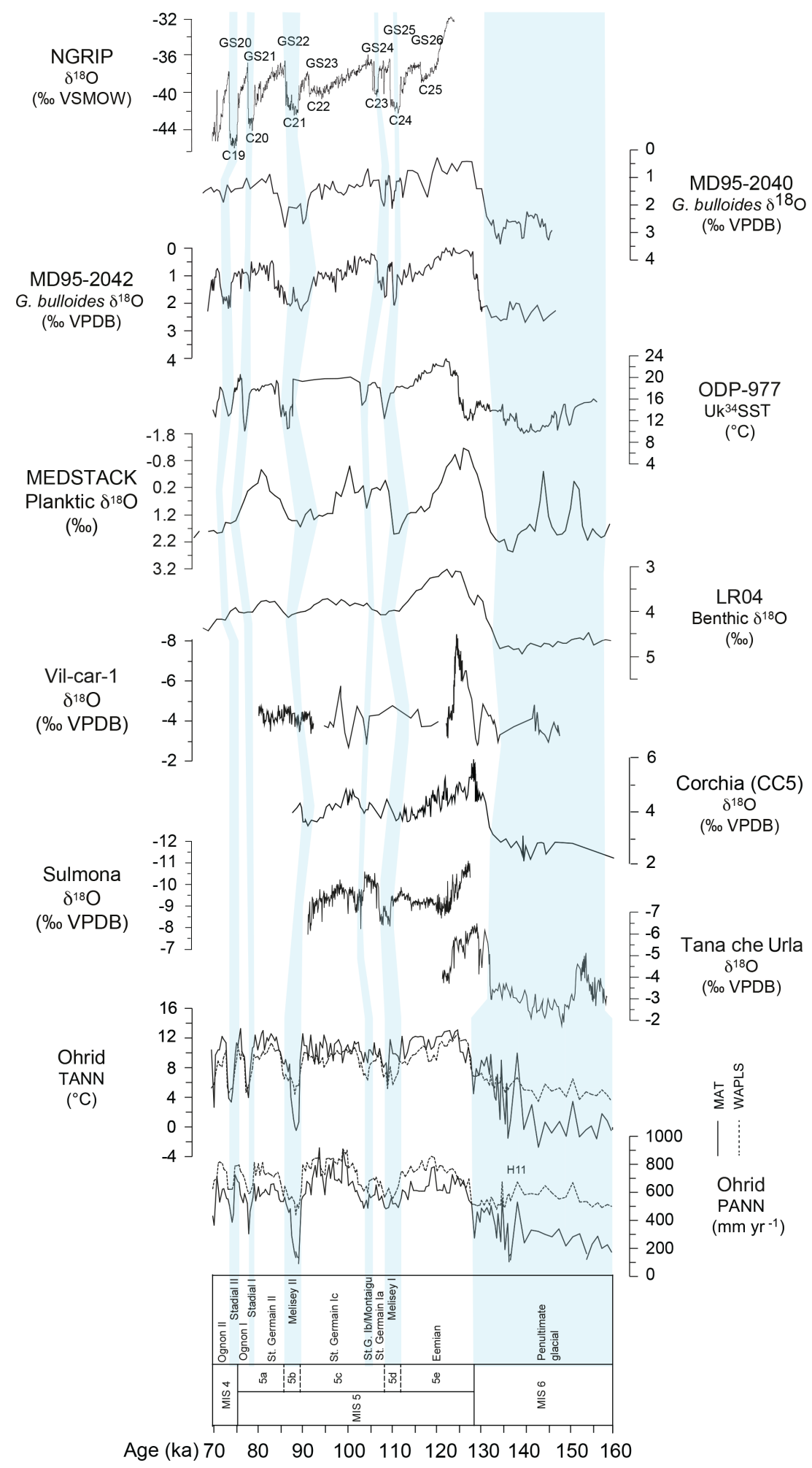

Figure 7. Comparison of TANN and PANN values from Lake Ohrid with other hydrological and climate proxies from the Mediterranean and the North Atlantic: $\delta^{18} \mathrm{O}$ speleothem record from Tana che Urla cave and $\delta^{18} \mathrm{O}$ of endogenic calcite from Sulmona lake (Regattieri et al., 2017 and 2014, respectively); $\delta^{18} \mathrm{O}$ speleothem record from Corchia cave (CC5, Drysdale et al., 2005); $\delta^{18} \mathrm{O}$ benthic from LR04 stack (Lisiecki and Raymo, 2005); planktic $\delta^{18}$ O from MEDSTACK data (Wang et al., 2010); sea surface temperature (SST) from core ODP-977 (Western Mediterranean; Martrat et al., 2004); planktic $\delta^{18}$ O from Iberian margin (MD95-2042; Sánchez Goñi et al., 1999; Sánchez Goñi et al., 2005); planktic $\delta^{18}$ O from Iberian margin (MD95-2040, De Abreu et al., 2003); Greenland $\delta^{18}$ O record (NGRIP Members, 2004). Numbers denote Greenland stadials (GS) corresponding to North Atlantic cold events (C events; after McManus et al., 1994). Blue shading indicates cold periods (penultimate glacial and early last glacial stadials).

Clim. Past, 15, 53-71, 2019

www.clim-past.net/15/53/2019/ 
the North Atlantic thermohaline circulation and the North Atlantic deep-water formation shut down with a consequent phase of cooler and drier conditions for mid-latitude western Europe (Genty et al., 2003). At Lake Ohrid (Fig. 7), H11 is clearly detected for the first time in a climate reconstruction, and in the TIC records of the DEEP core and Co1202 core (Figs. 4, 7).

Important changes during the LI have also been detected, besides at Lake Ohrid, in the alkenone-based sea surface temperature (SST) reconstruction of the ODP-977 sediment core (Alboran Basin; Martrat et al., 2004) in $\delta^{18} \mathrm{O}$ records of the Iberian margin (MD95-2042 and MD95-2040; Sánchez Goñi et al., 1999, 2005; De Abreu et al., 2003) and from Greenland (Fig. 7), in line with other studies on speleothems and on Mediterranean and North Atlantic marine records (e.g. De Abreu et al., 2003; Demény et al., 2017; Drysdale et al., 2009; Lisiecki and Raymo, 2005; Martrat et al., 2007, 2014; McManus, et al., 1994; Mokeddem et al., 2014; NGRIP Members, 2004; Oppo et al., 2006; Sánchez Goñi et al., 1999, 2005; Wang et al., 2010). Based on the ODP-977 alkenone data (Martrat et al., 2004, 2014), warm SSTs occurred during interstadial periods, while cold SSTs persisted during stadials Melisey I and II. SST changes are associated with large shifts in mean annual air temperature and moisture content as reflected in vegetation changes inferred from pollen analysis in European and Mediterranean records (Martrat et al., 2004; Tzedakis et al., 2003). The connection between Lake Ohrid and the North Atlantic (Fig. 7) is also highlighted by the evidence of the Melisey I stadial, which corresponds to the North Atlantic event C24 (and to GS25), the Montaigu event, corresponding to C23 (and GS24), and the Melisey II stadial, which corresponds to C21 (and GS22). Besides this event, the final part of MIS 5 at the transition to MIS 4 at Lake Ohrid is characterized by a series of abrupt climate changes (Ognon I and II phases) composed of two interstadials and two stadials. The latter correspond to the North Atlantic cold events C20 (GS21) and C19 (GS20) (Fig. 7). A similar pattern can be depicted in the SST record of ODP977 (Fig. 7) with two abrupt warming events, preceded by a strong cooling after a long period of stability (Martrat et al., 2014).

\section{Conclusions}

We provide a quantitative reconstruction of climate parameters based on the pollen record from Lake Ohrid (DEEP site), using two complementary approaches for the period between 160 and $70 \mathrm{ka}$. This period covers the last part of the penultimate glaciation, equivalent to MIS 6 (160-128 ka), and the Last Interglacial Complex (LIC, 128-70 ka), equivalent to MIS 5, as well as the first part of MIS 4.

Our results for the LIC show an alternation of warm and wet periods (128-112, 108-90.2, 85.7-78.8, 77.6-75 and $73.4-70 \mathrm{ka}$ ) with cold and dry ones (112-108, 105.2-
$104,90.2-85.7,78.8-77.6$ and $75-73.4 \mathrm{ka}$ ) attributable to the well-known succession of climatic events occurring during MIS 6 and 5.

With regard to the last interglacial, our results provide evidence that the Eemian was not as stable, confirming existing studies. The climate reconstruction led to distinguish three periods: a climatic optimum (128-121 ka), followed by progressive cooling in conjunction with an increase in precipitation (121-118 ka), and, finally, a period characterized by a decrease in both temperatures and precipitation (118$112 \mathrm{ka})$.

The early last glacial (from 112 to $70 \mathrm{ka}$ ) is characterized by a succession of cold and warm periods (stadials and interstadials) in which cold ones show an increase in seasonality and dry conditions. This climatic trend can be correlated to the succession of Greenland stadials and of North Atlantic cold events (Dansgaard et al., 1993; GRIP Members, 1993), illustrating the teleconnections between the North Atlantic realm and the Mediterranean region. The same succession of cold and dry events at Lake Ohrid is also coherent with hydrological and isotopic data from the central Mediterranean.

At a wider scale, our results showed a great similarity between Lake Ohrid and climate reconstructions of French and central European records rather than the stacked curve of four southern European records. Lake Ohrid shows intermediate features between these two areas; our curves are in line with those of other southern European climate proxies (e.g. central Italian speleothems). Future climate reconstructions and independent proxies are needed for the southern Mediterranean to resolve the complex regional expressions of past climate changes.

Data availability. Pollen data from the first $500 \mathrm{ka}$ years of the sequence (Sadori et al., 2016) are available through the online database PANGAEA at https://doi.org/10.1594/PANGAEA.892362 (Sadori et al., 2018). Higher resolution pollen data (Sinopoli et al., 2018) and climate reconstruction data (this paper) are not public yet as they will be part of further elaborations by authors of this article.

Supplement. The supplement related to this article is available online at: https://doi.org/10.5194/cp-15-53-2019-supplement.

Author contributions. The paper was written by GS, LS (all sections) and OP (Sects. 3, 4, 5, 6) with substantial contributions from BW, AF, JH (Sects. 1, 2, 5, 6) and AM (Sects. 1, 4, 5, 6). Data analysis was carried out by GS with the supervision of OP. Data management and the elaboration of figures and diagrams have been provided by GS and AM.

Competing interests. The authors declare that they have no conflict of interest. 
Acknowledgements. This work was developed in the frame of the joint PhD in Earth Sciences between the University of Rome "La Sapienza" (XXX cycle) and the University of Montpellier of Gaia Sinopoli. Moreover, Gaia Sinopoli acknowledges the Vinci programme, which granted her mobility between the two universities. This is an ISEM contribution.

The authors thank the palynological team involved in the SCOPSCO project. The drilling of the DEEP core was funded by ICDP, the German Ministry of Higher Education and Research, the German Research Foundation (DFG), the University of Cologne, the British Geological Survey, the INGV and CNR of Italy, and the governments of the Republic of Macedonia (FYROM) and Albania. Logistic support was provided by the Hydrobiological Institute in Ohrid. Drilling was carried out by Drilling, Observation and Sampling of the Earth's Continental Crust's (DOSECC) and using the Deep Lake Drilling System (DLDS).

Edited by: Nathalie Combourieu Nebout Reviewed by: three anonymous referees

\section{References}

Allen, J. R. M., Watts, W. A., and Huntley, B.: Weichselian palynostratigraphy, palaeovegetation and palaeoenvironment: the record from Lago Grande di Monticchio, southern Italy, Quatern. Int., 73/74, 91-110, 2000.

Bard, E., Delaygue, G., Rostek, F., Antonioli, F., Silenzi, S., and Schrag, D. P.: Hydrological conditions over the western Mediterranean basin during the deposition of the cold Sapropel 6 (ca. 175 Kyr BP), Earth Planet. Sc. Lett., 202, 481-494, 2002.

Bertini, A., Sadori, L., Combourieu-Nebout, N., Donders, T. H., Kouli, K., Koutsodendris, A., Joannin, S., Masi, A., Mercuri, A. M., Panagioutopulos, K., Peyron, O., Sinopoli, G., Torri, P., Zanchetta, G., Francke, A., and Wagner, B.: All together now: an international palynological team documents vegetation and climate changes during the last $500 \mathrm{kyr}$ at lake Ohrid (SE Europe), Alp. Mediterr. Quaternary, 29, 201-210, 2016.

Birks, H. J. B., Heiri, O., Seppä, H., and Bjune, A. E.: Strengths and weaknesses of quantitative climate reconstructions based on late Quaternary biological proxies, Open Ecol. J., 3, 68-110, 2010.

Bond, G. C., and Lotti, R.: Iceberg discharges into the North Atlantic on millennial time scales during the last glaciation, Science, 267, 1005-1010, 1995.

Bond, G. C., Heinrich, H., Broecker, W., Labeyrie, L., McManus, J., Andrews, J., Huon, S., Jantschik, R., Clasen, S., Simet, C., Tedesco, K., Klas, M., Bonani, G., and Ivy, S.: Evidence for massive discharges of icebergs into the North Atlantic Ocean during the last glacial period, Nature, 360, 245-249, 1992.

Bordon, A.: Dynamique de la vegetation et variations climatiques dans les Balkans au cours du dernier cycle climatique à partir des sequences polliniques des lacs Maliq et Ohrid (Albanie), Université de Franche-Comté, Phd thesis, 2008.

Brewer, S., Guiot, J., Sánchez-Goñi, M. F., and Klotz, S.: The climate in Europe during the Eemian: a multi-method approach using pollen data, Quaternary Sci. Rev., 27, 2303-2315, 2008.

Cheddadi, R., Mamakowa, K., Guiot, J., Beaulieu, J. L. de, Reille, M., Andrieu, V., Granoszewski, W., and Peyron, O.: Was the climate of the Eemian stable? A quantitative climate reconstruc- tion from seven European pollen records, Palaeogeogr. Palaeocl., 143, 73-85, 1998.

Dansgaard, W., Johnsen, S. J., Clausen, H. B., Dahl, J. D., Gundestrup, N. S., Hammer, C. U., Hvidberg, C. S., Steffensen, J. P., Sveinbjornsdottir, A. E., Jouzel, J., and Bond, G.: Evidence for general instability of past climate from a 250-kyr ice-core record, Nature, 364, 218-220, 1993.

De Abreu, L., Shackleton, N. J., Schönfeld, J., Hall, M., and Chapman, M.: Millennial-scale oceanic climate variability off the Western Iberian margin during the last two glacial periods, Mar. Geol., 196, 1-20, 2003.

de Beaulieu, J.-L. and Reille, M.: A long upper Pleistocene pollen record from Les Echets near Lyon, France, Boreas, 13, 111-132, 1984.

de Beaulieu, J.-L. and Reille, M.: The transition from temperate phases to stadials in the long Upper Pleistocene sequence from les Echets (France), Palaeogeogr. Palaeocl., 72, 147-159, 1989.

de Beaulieu, J. L. and Reille, M.: Long Pleistocene pollen sequences from the Velay Plateau (Massif Central, France), Veg. Hist. Archaeobot., 1, 233-242, 1992.

Demény, A., Czuppon, G., Siklósy, Z., Leél-Őssy, S., Chuan-Chou Shen, K. L., and Gulyás, K.: Stable isotope compositions of speleothems from the last interglacial - Spatial patterns of climate fluctuations in Europe, Quaternary Sci. Rev., 161, 68-80, 2017.

Drysdale, R. N., Zanchetta, G., Hellstrom, J. C., Fallick, A. E., and Zhao, J. X.: Stalagmite evidence for the onset of the Last Interglacial in southern Europe at $129 \pm 1 \mathrm{ka}$, Geophys. Res. Lett., 32, $1-4,2005$.

Drysdale, R. N., Hellstrom, J. C., Zanchetta, G., Fallick, A., Goni, M. S., Chouchoud, I. McDonald, J., Maas, R., Lohman, G., and Isola, I.: Evidence for obliquity forcing of glacial termination II, Science, 325, 1527-1531, 2009.

Fauquette, S., Guiot, J., Menut, M., Beaulieu, J.-L. de, Reille, M., and Guenet, P.: Vegetation and climate since the last interglacial in the Vienne area (France), Global Planet. Change, 20, 1-17, 1999.

Field, M. H., Huntley, B., and Müller, H.: Eemian climate fluctuations observed in a European pollen record, Nature, 371, 779783, 1994.

Francke, A., Wagner, B., Just, J., Leicher, N., Gromig, R., Baumgarten, H., Vogel, H., Lacey, J. H., Sadori, L., Wonik, T., Leng, M. J., Zanchetta, G., Sulpizio, R., and Giaccio, B.: Sedimentological processes and environmental variability at Lake Ohrid (Macedonia, Albania) between $637 \mathrm{ka}$ and the present, Biogeosciences, 13, 1179-1196, https://doi.org/10.5194/bg-131179-2016, 2016.

Genty, D., Blamart, D., Ouahdi, R., and Gilmour, M.: Precise dating of Dansgaard-Oeschger climate oscillations in western Europe from stalagmite data, Nature, 421, 833-837, 2003.

Govin, A., Capron, E., Tzedakis, P. C., Verheyden, S., Ghaleb, B., Hillaire-Marcel, C., St-Onge, G., Stoner, G. S., Bassinot, F., Bazin, L., Blunier, T., Comborieu-Nebout, N., and Ouahabi, E. I.: Sequence of events from the onset to the demise of the Last Interglacial: Evaluating strengths and limitations of chronologies used in climatic archives, Quaternary Sci. Rev., 129, 1-36, 2015.

GRIP Members: Climate instability during the last interglacial period recorded in the GRIP ice core, Nature, 364, 203-207, 1993. 
Guiot, J.: Late Quaternary climatic change in France estimated from multivariate pollen time series, Quaternary Res., 28, 100-118, 1987.

Guiot, J.: Methodology of palaeoclimatic reconstruction from pollen in France, Palaeogeogr. Palaeocl., 80, 49-69, 1990.

Guiot, J., Pons, A., Beaulieu, J. L. de, and Reille, M.: A 140,000year continental climate reconstruction from two European pollen records, Nature, 338, 309-313, 1989.

Guiot, J., Beaulieu, J. L. de, Cheddadi, R., David, F., Ponel, P., and Reille, M.: The climate in Western Europe during the last Glacial/Interglacial cycle derived from pollen and insect remains, Palaeogeogr. Palaeocl., 103, 73-93, 1993.

Holtvoeth, J., Vogel, H., Valsecchi, V., Lindhorst, K., Schouten, S., Wagner, B., and Wolff, G. A.: Linear and non-linear responses of vegetation and soils to glacial-interglacial climate change in a Mediterranean refuge, Sci. Rep., 7, 8121, https://doi.org/10.1038/s41598-017-08101-y, 2017.

Juggins, S.: Package "rioja" - Analysis of Quaternary Science Data, version 0.9-6, The Comprehensive R Archive Network, 2016.

Kaspar, F., Kühl, N., Cubasch, U., and Litt, T.: A modeldata comparison of European temperatures in the Eemian interglacial, Geophys. Res. Lett., 32, L11703, https://doi.org/10.1029/2005GL022456, 2005.

Keigwin, L. D., Curry, W. B., Lehman, S. J., and Johnsen, S.: The role of the deep ocean in North Atlantic climate change between 70 and $130 \mathrm{kyr}$ ago, Nature, 371, 323-325, 1994.

Klotz, S., Guiot, J., and Mosbrugger, V.: Continental European Eemian and early Würmian climate evolution: comparing signals using different quantitative reconstruction approaches based on pollen, Global Planet. Change, 36, 277-294, 2003.

Klotz, S., Müller, U., Mosbrugger, V., Beaulieu, J. L. de, and Reille, M.: Eemian to early Würmian climate dynamics: history and pattern of changes in Central Europe, Palaeogeogr. Palaeocl., 211, 107-126, 2004.

Kopp, R. E., Simons, F. J., Mitrovica, J. X., Maloof, A. C., and Oppenheimer, M.: Probabilistic assessment of sea level during the last interglacial, Nature, 462, 863-867, 2009.

Kühl, N. and Litt, T.: Quantitative time series reconstruction of Eemian temperature at three European sites using pollen data, Veget. Histor. Archaeobot., 12, 205-214, 2003.

Kühl, N., Moschen, R., Wagner, S., Brewer, S., and Peyron, O.: A multiproxy record of Late Holocene natural and anthropogenic environmental change from the Sphagnum peat bog Dürres Maar, Germany: implications for quantitative climate reconstructions based on pollen, J. Quaternary Sci., 25, 675-688, 2010.

Leicher, N., Zanchetta, G., Sulpizio, R., Giaccio, B., Wagner, B., Nomade, S., Francke, A., and Del Carlo, P.: First tephrostratigraphic results of the DEEP site record from Lake Ohrid (Macedonia and Albania), Biogeosciences, 13, 2151-2178, https://doi.org/10.5194/bg-13-2151-2016, 2016.

Lézine, A. M., Von Grafenstein, U., Andersen, N., Belmecheri, S., Bordon, A., Caron, B., Cazet, J. P., Erlenkeuser, H., Fouache, E., Grenier, C., Huntsman-Mapila, P., Hureau-Mazaudier, D., Manelli, D., Mazaud, A., Robert, C., Sulpizio, R., Tiercelin, J. J., Zanchetta, G., and Zeqollari, Z.: Lake Ohrid, Albania, provides an exceptional multi-proxy record of environmental changes during the last glacial-interglacial cycle, Palaeogeogr. Palaeocl., 287, 116-127, 2010.
Lindhorst, K., Vogel, H., Krastel, S., Wagner, B., Hilgers, A., Zander, A., Schwenk, T., Wessels, M., and Daut, G.: Stratigraphic analysis of lake level fluctuations in Lake Ohrid: an integration of high resolution hydro-acoustic data and sediment cores, Biogeosciences, 7, 3531-3548, https://doi.org/10.5194/bg-7-35312010, 2010.

Lisiecki, L. E. and Raymo, M. E.: A Pliocene-Pleistocene stack of 57 globally distributed benthic $\delta^{18} \mathrm{O}$ records, Paleoceanography, 20, 1003, https://doi.org/10.1029/2004PA001071, 2005.

Litt, T., Junge, F. W., and Böttger, T.: Climate during the Eemian in north-central Europe a critical review of the palaeobotanical and stable isotope data from central Germany, Veget. Hist. Archaeobot., 5, 247-256, 1996.

Martrat, B., Grimalt, J. O., Lopez-Martinez, C., Cacho, I., Sierro, F. J., Flores, J. A., Zahn, R., Canals, M., Curtis, J. H., and Hodell, D. A.: Abrupt temperature changes in the Western Mediterranean over the past 250,000 years, Science, 306, 1762-1765, 2004.

Martrat, B., Grimalt, J. O., Shackleton, N. J., de Abreu, L., Hutterli, M. A., and Stocker, T. F.: Four climate cycles of recurring deep and surface water destabilizations on the Iberian margin, Science, 317, 502-507, 2007.

Martrat, B., Jimenez-Amat, P., Zahn, R., and Grimalt, J. O.: Similarities and dissimilarities between the last two deglaciations and interglaciations in the North Atlantic region, Quaternary Sci. Rev., 99, 122-134, 2014.

Maslin, M. A. and Tzedakis, P. C.: Last Interglacial Gets Sudden Chill, Eos, 77, 353-354, 1996.

Mauri, A., Davis, B. A. S., Collins, P. M., and Kaplan, J. O.: The climate of Europe during the Holocene: a gridded pollen-based reconstruction and its multi-proxy evaluation, Quaternary Sci. Rev., 112, 109-127, 2015.

McManus, J. F., Bond, G. C., Broecker, W. S., Johnsen, S., Labeyrieš, L., and Higgins, S.: High-resolution climate records from the North Atlantic during the last interglacial, Nature, 371, 326-329, 1994.

McManus, J. F., Oppo, D. W., and Cullen, J. L.: A 0.5-millionyear record of millennial-scale climate variability in the North Atlantic, Science, 283, 971-975, 1999.

Milner, A. M., Roucoux, K. H., Collier, R. E. L., Müller, U. C., Pross, J., and Tzedakis, P. C.: Vegetation responses to abrupt climatic changes during the Last Interglacial Complex (Marine Isotope Stage 5) at Tenaghi Philippon, NE Greece, Quaternary Sci. Rev., 154, 169-181, 2016.

Mokeddem, Z., McManus, J. F., and Oppo, D. W.: Oceanographic dynamics and the end of the last interglacial in the subpolar North Atlantic, P. Natl. Acad. Sci. USA, 111, 11263-11268, 2014.

Müller, U. C., Pross, J., Tzedakis, P. C., Gamble, C., Kotthoff, U., Schmiedl, G., Wulf, S., and Christanis, K: The role of climate in the spread of modern humans into Europe, Quaternary Sci. Rev., 30, 273-279, 2011.

NGRIP Members: High-resolution record of Northern Hemisphere climate extending into the last interglacial period, Nature, 431, 147-151, 2004.

Okuda, M., Yasuda, Y., and Setoguchi, T.: Middle to Late Pleistocene vegetation history and climatic changes at Lake Kopais, Southeast Greece, Boreas, 30, 73-82, 2001.

Oppo, D. W., McManus, J. F., and Cullen, J. L.: Evolution and demise of the Last Interglacial warmth in the subpolar North Atlantic, Quaternary Sci. Rev., 25, 3268-3277, 2006. 
Otto-Bliesner, B. L., Rosenbloom, N., Stone, E. J., McKay, N. P., Lunt, D. J., Brady, E. C., and Overpeck, J. T.: How warm was the last Interglacial? New model-data comparisons, Philos. T. R. Soc. A, 371, 20130097, https://doi.org/10.1098/rsta.2013.0097, 2013.

Overpeck, J. T., Otto-Bliesner, B. L., Miller, G. H., Muhs, D. R., Alley, R. B., and Kiehl, J. T.: Paleoclimatic evidence for future ice-sheet instability and rapid sea-level rise, Science, 311, 17471750, 2006.

Panagiotopoulos, K., Böhm, A., Leng, M. J., Wagner, B., and Schäbitz, F.: Climate variability over the last $92 \mathrm{ka}$ in SW Balkans from analysis of sediments from Lake Prespa, Clim. Past, 10, 643-660, https://doi.org/10.5194/cp-10-6432014, 2014.

Peyron, O., Guiot, J., Cheddadi, R., Tarasov, P., Reille, M., Beaulieu, J. L. de, Bottema, S., and Andrieu, V.: Climatic reconstruction in Europe for 18,000 yr BP from pollen data, Quaternary Res., 49, 183-196, 1998.

Peyron, O., Bégeot, C., Brewer, S., Heiri, O., Magny, M., Millet, L., Ruffaldi, P., Van Campo, E., and Yu, G.: Lateglacial climate in the Jura Mountains based on pollen, lake-levels, and chironomids, Quaternary Res., 64, 197-211, 2005.

Peyron, O., Goring, S., Dormoy, I., Kotthoff, U., Pross, J., Beaulieu, J. L. de, Drescher-Schneider, R., Vannière, B., and Magny, M.: Holocene seasonality changes in the central Mediterranean region reconstructed from the pollen sequences of Lake Accesa (Italy) and Tenaghi Philippon (Greece), Holocene, 21, 131-146, 2011.

Peyron, O., Magny, M., Goring, S., Joannin, S., de Beaulieu, J.L., Brugiapaglia, E., Sadori, L., Garfi, G., Kouli, K., Ioakim, C., and Combourieu-Nebout, N.: Contrasting patterns of climatic changes during the Holocene across the Italian Peninsula reconstructed from pollen data, Clim. Past, 9, 1233-1252, https://doi.org/10.5194/cp-9-1233-2013, 2013.

Pickarski, N., Kwiecien, O., Djamali, M., and Litt, T.: Vegetation and environmental changes during the last interglacial in eastern Anatolia (Turkey): a new high-resolution pollen record from Lake Van, Palaeogeogr. Palaeocl., 435, 145-158, 2015.

Pons, A., Guiot, J., Beaulieu, J. L. de, and Reille, M.: Recent contributions to the climatology of the last glacial-interglacial cycle based on French pollen sites, Quaternary Sci. Rev., 11, 439-448, 1992.

Railsback, L. B., Gibbard, P. L., Head, M. J., Voarintsoa, N. R. G., and Toucanne, S.: An optimized scheme of lettered marine isotope substages for the last 1.0 million years, and the climatostratigraphic nature of isotope stages and substages, Quaternary Sci. Rev., 111, 94-106, 2015.

Rasmussen, S. O., Bigler, M., Blockley, S. P. E., Blunier, T., Buchardt, S. L., Clausen, H. B., Cvijanovic, I., Dahl-Jensen, D., Johnsen, S. J., Fischer, H., Gkinis, V., Guillevic, M., Hoek, W. Z., Lowe, J. J., Pedro, J., Popp, T., Seierstad, I., Steffensen, J. P., Svensson, A. M., Vallelonga, P., Vinther, B. M., Walker, M. J. C., Wheatley, J. J., and Winstrup, M.: A stratigraphic framework for robust naming and correlation of past abrupt climatic changes during the last glacial period based on three synchronized Greenland ice core records, Quaternary Sci. Rev., 106, 14-28, 2014.

Raymo, M. E., Ruddiman, W. F., Backman, J., Clement, B. M., and Martinson, D. G.: Late Pliocene variation in Northern Hemi- sphere ice sheets and North Atlantic deep water circulation, $\mathrm{Pa}$ leoceanography, 4, 413-446, 1989.

Regattieri, E., Zanchetta, G., Drysdale, R. N., Isola, I., Hellstrom, J. C., and Roncioni, A.: A continuous stable isotope record from the penultimate glacial maximum to the Last Interglacial (159$121 \mathrm{Ka}$ ) from Tana Che Urla Cave (Apuans Alps, central Italy), Quaternary Res., 82, 450-461, 2014.

Regattieri, E., Giaccio, B., Galli, P., Nomade, S., Peronace, E., Messina, P., Sposato, A., Boschi, C., and Gemelli, M.: A multiproxy record of MIS 11-12 deglaciation and glacial MIS 12 instability from the Sulmona Basin (central Italy), Quaternary Sci. Rev., 132, 129-145, 2016.

Regattieri, E., Giaccio, B., Nomade, S., Francke, A., Vogel, H., Drysdale, R. N., Perchiazzi, N., Wagner, B., Gemelli, M., Mazzini, I., Boschi, C., Galli, P., and Peronace, E.: A Last Interglacial record of environmental changes from the Sulmona Basin (central Italy), Palaeogeogr. Palaeocl., 472, 51-66, 2017.

Rioual, P., Andrieu-Ponel, V., Rietti-Shati, M., Battarbee, R. W., Beaulieu, J. L. de, Cheddadi, R., Reille, M., Svoboda, H., and Shemesh, A.: High-resolution record of climate stability in France during the last interglacial period, Nature, 413, 293-296, 2001.

Rousseau, D.-D., Hatte, C., Guiot, J., Duzer, D., Schevin, P., and Kukla, G.: Reconstruction of the Grande Pile Eemian using inverse modeling of biomes and $\delta^{13} \mathrm{C}$, Quaternary Sci. Rev., 25, 2806-2819, 2006.

Sadori, L., Koutsodendris, A., Panagiotopoulos, K., Masi, A., Bertini, A., Combourieu-Nebout, N., Francke, A., Kouli, K., Joannin, S., Mercuri, A. M., Peyron, O., Torri, P., Wagner, B., Zanchetta, G., Sinopoli, G., and Donders, T. H.: Pollen-based paleoenvironmental and paleoclimatic change at Lake Ohrid (south-eastern Europe) during the past $500 \mathrm{ka}$, Biogeosciences, 13, 1423-1437, https://doi.org/10.5194/bg-13-1423-2016, 2016.

Sadori, L., Koutsodendris, A., Panagiotopoulos, K., Masi, A., Bertini, A., Combourieu-Nebout, N., Francke, A., Kouli, K., Kousis, I., Joannin, S., Mercuri, A. M., Peyron, O., Torri, P., Wagner, B., Zanchetta, G., Sinopoli, G., and Donders, T. H.: Pollen data of the last $500 \mathrm{ka} \mathrm{BP}$ at Lake Ohrid (south-eastern Europe), PANGAEA, https://doi.org/10.1594/PANGAEA.892362, 2018.

Sánchez-Goñi, M. F.: 13 - Introduction to climate and vegetation in Europe during MIS5, Developments in Quaternary Sciences, 7, 197-205, 2007.

Sánchez-Goñi, M. F., Eynaud, F., Turon, J. L., and Shackleton, N. J.: High resolution palynological record off the Iberian margin: direct land-sea correlation for the Last Interglacial complex, Earth Planet. Sc. Lett., 171, 123-137, 1999.

Sánchez-Goñi, M. F., Turon, J. L., Eynaud, F., Shackleton, N. J., and Cayre, O.: Direct land/sea correlation of the Eemian, and its comparison with the Holocene: a high-resolution palynological record off the Iberian margin, Geologie Mijnbouw, 79, 345-354, 2000.

Sánchez-Goñi, M. F., Loutre, M. F., Crucifix, M., Peyron, O., Santos, L., Duprat, J., Malaizé, B., Turon, J. L., and Peypouquet, J. P.: Increasing vegetation and climate gradient in Western Europe over the Last Glacial Inception (122-110 ka): data-model comparison, Earth Planet. Sc. Lett., 231, 111-130, 2005.

Sánchez-Goñi, M. F., Bakker, P., Desprat, S., Carlson, A. E., Van Meerbeeck, C. J., Peyron, O., Naughton, F., Fletcher, W. J., Ey- 
naud, F., Rossignol, L., and Renssen, H.: European climate optimum and enhanced Greenland melt during the Last Interglacial, Geology, 40, 627-630, 2012.

Shackleton, N. J., Chapman, M., Sánchez-Goñi, M. F., Pailler, D., and Lancelot, Y.: The classic marine isotope substage 5e, Quaternary Res., 58, 14-16, 2003.

Sinopoli, G., Masi, A., Regattieri, E., Wagner, B., Francke, A., Peyron, O., and Sadori, L.: Palynology of the Last Interglacial Complex at Lake Ohrid: palaeoenvironmental and palaeoclimatic inferences, Quaternary Sci. Rev., 180, 177-192, 2018.

Sirocko, F., Seelos, K., Schaber, K., Rein, B., Dreher, F., Diehl, M., Lehne, R., Jager, K., Krbetschek, M., and Degering, D.: A late Eemian aridity pulse in central Europe during the last glacial inception, Nature, 436, 833-836, 2005.

Tarasov, P. E., Cheddadi, R., Guiot, J., Bottema, S., Peyron, O., Belmonte, J., Ruiz-Vasquez, V., Saadi, F., and Brewer, S.: A method to determine warm and cool steppe biomes from pollen data; application to the Mediterranean and Kazakhstan regions, J. Quaternary Sci., 13, 335-344, 1998.

Ter Braak, C. J. F. and van Dam, H.: Inferring pH from diatoms: A comparison of old and new calibration methods, Hydrobiologia, 178, 209-223, 1989.

Ter Braak, C. J. F. and Juggins, S.: Weighted averaging partial least squares regression (WA-PLS): An improved method for reconstructing environmental variables from species assemblages, Hydrobiologia, 269/270, 485-502, 1993.

Turner, C.: Formal status and vegetational development of the Eemian interglacial in northwestern and southern Europe, Quaternary Res., 58, 41-44, 2002.

Turney, C. S. and Jones, R. T.: Does the Agulhas Current amplify global temperatures during super-interglacials?, J. Quaternary Sci., 25, 839-843, 2010.

Tzedakis, P. C.: Vegetation Change through Glacial-Interglacial Cycles: A Long Pollen Sequence Perspective, Philos. T. R. Soc. Lond. B, 345, 403-432, 1994.

Tzedakis, P. C.: The last climatic cycle at Kopais, central Greece, J. Geol. Soc., 156, 425-434, 1999.

Tzedakis, P. C.: Seven ambiguities in the Mediterranean palaeoenvironmental narrative, Quaternary Sci. Rev., 26, 2042-2066, 2007.

Tzedakis, P. C., Andrieu, V., De Beaulieu, J. L., Crowhurst, S. D., Follieri, M., Hooghiemstra, H., Magri, D., Reille. M., Sadori, L., Shackleton N. J., and Wijmstra, T. A.: Comparison of terrestrial and marine records of changing climate of the last 500,000 years, Earth Planet. Sc. Lett., 150, 171-176, 1997.

Tzedakis, P. C., McManus, J. F., Hooghiemstra, H., Oppo, D. W., and Wijmstra, T. A.: Comparison of changes in vegetation in northeast Greece with records of climate variability on orbital and suborbital frequencies over the last 450000 years, Earth Planet. Sc. Lett., 212, 197-212, 2003.
Vogel, H., Wagner, B., Zanchetta, G., Sulpizio, R., and Rosén, P.: A paleoclimate record with tephrochronological age control for the last glacial-interglacial cycle from Lake Ohrid, Albania and Macedonia, J. Paleolimnol., 44, 295-310, 2010.

Wagner, B., Wilke, T., Francke, A., Albrecht, C., Baumgarten, H., Bertini, A., Combourieu-Nebout, N., Cvetkoska, A., D’Addabbo, M., Donders, T. H., Föller, K., Giaccio, B., Grazhdani, A., Hauffe, T., Holtvoeth, J., Joannin, S., Jovanovska, E., Just, J., Kouli, K., Koutsodendris, A., Krastel, S., Lacey, J. H., Leicher, N., Leng, M. J., Levkov, Z., Lindhorst, K., Masi, A., Mercuri, A. M., Nomade, S., Nowaczyk, N., Panagiotopoulos, K., Peyron, O., Reed, J. M., Regattieri, E., Sadori, L., Sagnotti, L., Stelbrink, B., Sulpizio, R., Tofilovska, S., Torri, P., Vogel, H., Wagner, T., Wagner-Cremer, F., Wolff, G. A., Wonik, T., Zanchetta, G., and Zhang, X. S.: The environmental and evolutionary history of Lake Ohrid (FYROM/Albania): interim results from the SCOPSCO deep drilling project, Biogeosciences, 14, 2033-2054, https://doi.org/10.5194/bg-14-2033-2017, 2017.

Wang, P., Tian, J., and Lourens, L.: Obscuring of long eccentricity cyclicity in Pleistocene oceanic carbon isotope records, Earth Planet. Sc. Lett, 290, 319-330, 2010.

Woillard, G.: Grande Pile Peat Bog: a continuous pollen record for the last 140.000 years, Quaternary Res., 9, 1-21, 1978.

Zagwijn, W. H.: An analysis of Eemian climate in Western and Central Europe, Quaternary Sci. Rev., 15, 451-469, 1996.

Zanchetta, G., Drysdale, R. N., Hellstrom, J. C., Fallick, A. E., Isola, I., Gagan, M., and Pareschi, M. T.: Enhanced rainfall in the western Mediterranean during deposition of sapropel S1: Stalagmite evidence from Corchia Cave (Central Italy), Quaternary Sci. Rev., 30, 279-286, 2007.

Zanchetta, G., Regattieri, E., Giaccio, B., Wagner, B., Sulpizio, R., Francke, A., Vogel, H., Sadori, L., Masi, A., Sinopoli, G., Lacey, J. H., Leng, M. J., and Leicher, N.: Aligning and synchronization of MIS5 proxy records from Lake Ohrid (FYROM) with independently dated Mediterranean archives: implications for DEEP core chronology, Biogeosciences, 13, 2757-2768, https://doi.org/10.5194/bg-13-2757-2016, 2016.

Zanchetta, G., Baneschi, I., Francke, A., Boschi, C., Regattieri, E., Wagner, B., Lacey, J. H., Leng, M., J., Vogel, H., and Sadori, L.: Evidence for carbon cycling in a large freshwater lake in the Balkans over the last 0.5 million years using the isotopic composition of bulk organic matter, Quaternary Sci. Rev., 202, 154165, https://doi.org/10.1016/j.quascirev.2018.10.022, 2018. 